\title{
Grassland production under global change scenarios for New Zealand pastoral agriculture
}

\author{
E. D. Keller ${ }^{1}$, W. T. Baisden ${ }^{1}$, L. Timar ${ }^{1,2}$, B. Mullan ${ }^{3}$, and A. Clark ${ }^{3, *}$ \\ ${ }^{1}$ GNS Science, Lower Hutt, New Zealand \\ ${ }^{2}$ Motu Economic and Public Policy Research, Wellington, New Zealand \\ ${ }^{3}$ NIWA, Wellington, New Zealand \\ * now at: New South Wales Department of Primary Industries, Orange, NSW, Australia \\ Correspondence to: E. D. Keller (1.keller@gns.cri.nz)
}

Received: 4 April 2014 - Published in Geosci. Model Dev. Discuss.: 12 May 2014

Revised: 15 September 2014 - Accepted: 15 September 2014 - Published: 16 October 2014

\begin{abstract}
We adapt and integrate the Biome-BGC and Land Use in Rural New Zealand models to simulate pastoral agriculture and to make land-use change, intensification of agricultural activity and climate change scenario projections of New Zealand's pasture production at time slices centred on 2020, 2050 and 2100, with comparison to a present-day baseline. Biome-BGC model parameters are optimised for pasture production in both dairy and sheep/beef farm systems, representing a new application of the Biome-BGC model. Results show up to a $10 \%$ increase in New Zealand's national pasture production in 2020 under intensification and a 1-2\% increase by 2050 from economic factors driving land-use change. Climate change scenarios using statistically downscaled global climate models (GCMs) from the IPCC Fourth Assessment Report also show national increases of 1$2 \%$ in 2050, with significant regional variations. Projected out to 2100, however, these scenarios are more sensitive to the type of pasture system and the severity of warming: dairy systems show an increase in production of $4 \%$ under mild change but a decline of $1 \%$ under a more extreme case, whereas sheep/beef production declines in both cases by 3 and $13 \%$, respectively. Our results suggest that high-fertility systems such as dairying could be more resilient under future change, with dairy production increasing or only slightly declining in all of our scenarios. These are the first nationalscale estimates using a model to evaluate the joint effects of climate change, $\mathrm{CO}_{2}$ fertilisation and $\mathrm{N}$-cycle feedbacks on New Zealand's unique pastoral production systems that dominate the nation's agriculture and economy. Model results emphasise that $\mathrm{CO}_{2}$ fertilisation and $\mathrm{N}$-cycle feedback
\end{abstract}

effects are responsible for meaningful differences in agricultural systems. More broadly, we demonstrate that our model output enables analysis of decoupled land-use change scenarios: the Biome-BGC data products at a national or regional level can be re-sampled quickly and cost-effectively for specific land-use change scenarios and future projections.

\section{Introduction}

Intensive pasture grazing systems dominate New Zealand's agricultural production, in contrast to the cultivated cropland and animal feeding operations that make up the majority of agriculture in other developed countries worldwide. In this respect New Zealand is unusual, with the national scale and economic importance of its pastoral agriculture system representing an extreme. The dairy and sheep/beef industries in particular are central to the New Zealand economy. Production from primary industries makes up $12 \%$ of New Zealand's GDP, of which the dairy industry alone contributes almost $3 \%$. Dairy products comprise over a quarter of New Zealand's total exports, with an export value of NZD 13.9 billion for the year 2011/12. Meat and wool exports are also significant, with beef and lamb export value at NZD 5.6 billion in 2011/12 (New Zealand Ministry for Primary Industries, 2012; Schilling et al., 2010). While sheep and beef farms still make up the majority of agricultural land, dairy farming is rapidly expanding in size and area, continuing a long-term decadal shift towards more intensive but historically more profitable dairy pasture. New Zealand's future 
pasture production thus features prominently in many national projections in economics, primary production and the environment, including water quality and climate change impacts and adaptation.

Consequently, there is a need to understand possible changes to the productivity of New Zealand's pastoral agriculture systems under a range of future scenarios. Because New Zealand depends almost exclusively on pasture for animal feed, climate change could have considerable effects on the nature and profitability of dairy and sheep/beef farming in the short and long term. In addition to economic considerations, pasture production estimates are crucial in addressing questions of environmental sustainability. Unlike most developed countries, whose greenhouse gas $(\mathrm{GHG})$ emissions are largely derived from fossil fuels and carbon dioxide $\left(\mathrm{CO}_{2}\right)$, almost half of New Zealand's GHG emissions arise from agriculture and methane $\left(\mathrm{CH}_{4}\right)$. Accurate estimates of pasture production are required to understand such questions as whether feed supply can become a limiting factor on the number of grazing animals used to calculate New Zealand's emissions of methane and nitrous oxide $\left(\mathrm{N}_{2} \mathrm{O}\right)$.

Complex environmental and policy questions such as these can be addressed through integrated modelling assessments of the impact of climatic, economic, and land management factors on future agricultural productivity. There are many examples of studies at the global, regional, and national level that couple dynamic biophysical process-based or statistical crop models with climate and land-use data sets to estimate quantities such as carbon flux and storage, net primary productivity (NPP) and water availability for both managed and natural ecosystems under future climate and management scenarios (Beer et al., 2010; Bondeau et al., 2007; Gumpenberger et al., 2010; Rost et al., 2009; Roudier et al., 2011). Coupling models in this way is important in accounting for non-linear feedbacks and interactions between climate, the carbon cycle, and land-use and management decisions, which can be quite significant (Ronneberger et al., 2006). Additionally, it is essential to integrate climate change effects and feedbacks into economic and policy assessments for their impact to be considered in the decision-making process and to affect long-term planning and preparedness.

The present study is intended to develop flexible output and data products at a national or regional level that enable the examination and analysis of a range of scenarios and their possible impacts on pasture production in New Zealand at particular time slices over the next 100 years. It builds on previous research efforts and existing data sets to understand some of the biophysical, climatic, economic, and land management variations that might affect the future productivity of New Zealand's pastoral agriculture. Like many small countries, New Zealand (population 4.5 million, land area $260000 \mathrm{~km}^{2}$ ) requires cost-effective model infrastructure that is capable of evaluating policy options on timescales of months or weeks. The development of the Land Use in Rural New Zealand (LURNZ) model meets this challenge and, importantly, enables the integration of global change scenarios with contemporary policy choices. Before outlining the rationale for our model infrastructure, it is useful to briefly review the history of integrated model development in New Zealand, primarily aimed at the climate change component of global change.

Earlier integrated modelling studies of New Zealand pasture include the 2001 CLIMPACTS study (Warrick et al., 2001), which used a global climate model in combination with New Zealand data sets to produce estimates of pasture production based on scenarios from the Intergovernmental Panel on Climate Change (IPCC) Second Assessment Report. The more recent EcoClimate Report (Stroombergen et al., 2008) estimated productivity for 2030 and 2080 for several agricultural sub-sectors, including sheep/beef and dairy pasture systems, and provided a preliminary integrated assessment of possible economic costs and benefits of climate change. National and regional projections were based on a climate-index approach (Baisden, 2006) and statistically downscaled scenarios from the HadCM2 model in the 2001 IPCC Third Assessment Report (Mullan et al., 2005). However, the methodology does not account for the potentially important effects of increased carbon dioxide concentrations in the atmosphere $\left(\mathrm{CO}_{2}\right.$ fertilisation) and the interaction with progressive nitrogen $(\mathrm{N})$ limitation. The earlier CLIMPACTS methodology accounted for $\mathrm{CO}_{2}$ fertilisation but not $\mathrm{N}$ limitation. These omissions could alter results substantially because studies involving the effect of $\mathrm{CO}_{2}$ fertilisation on plant physiology and growth suggest that plant biomass increases overall under elevated $\mathrm{CO}_{2}$, but the response depends strongly on nutrient ( $\mathrm{N}$ and $\mathrm{P}$ ) availability (Ainsworth and Long, 2005; de Graaff et al., 2006; Newton et al., 2010).

To address these concerns about the lack of $\mathrm{CO}_{2}-\mathrm{N}-$ climate interactions and feedbacks, and also to fulfil the need for a suitable temporal and spatial resolution, we use the Biome-BGC model. The model provides a level of complexity intermediate between simple climate-index-driven pasture production and a full farm system model (e.g. APSIM, Keating et al., 2003), which can be difficult to extrapolate across space and apply at a national scale. Biome-BGC is able to simulate daily climate variables, water availability and irrigation, $\mathrm{CO}_{2}$ fertilisation effects, all relevant nitrogen inputs and outputs, and the utilisation of pasture by grazing animals without requiring an overwhelming level of detail about individual farms.

We simulate the two dominant types of pasture systems in New Zealand, which we will refer to as "dairy" and "sheep/beef". The main difference between these two systems is the intensity of grazing, dairy being the more intensive of the two. Dairy farming is associated with highly productive pasture and therefore involves higher stocking rates, more nitrogen fertilisation, a larger amount of animal products extracted from the system, and often the addition of irrigation (which we do not model here). We develop model parameterisations for each type of pasture system that enables 
the simulation of national and regional pasture production for the present baseline and projections for future scenarios. By then sampling the model's output across land-use extents, we introduce analysis of decoupled land-use change scenarios (DLUCSs): the pasture data products at a national or regional level can be re-sampled quickly and cost-effectively for specific land-use change projections. This is a flexible approach that can be easily applied to many specific scenarios of climate and land-use change, not only the ones presented here. Herein, we describe our process of parameterising BiomeBGC for grazed pasture agro-ecosystems on a $\sim 5 \mathrm{~km}$ grid covering New Zealand, explain our methodology and choice of model scenarios, and report national production results for dairy and sheep/beef systems.

\section{Methods}

\subsection{Biome-BGC model}

The Biome-BGC (Bio-Geochemical Cycles) model v4.2 Final Release (Thornton et al., 2005) is an ecosystem process model that simulates the biological and physical processes controlling cycles of carbon, nitrogen and water of vegetation and soil in terrestrial ecosystems. The model is capable of simulating evergreen, deciduous and broadleaf forests, $\mathrm{C} 3$ and C4 grasslands, and shrub ecosystems. The primary input consists of weather conditions at a daily time step, as well as site-specific information such as elevation, soil composition and rooting depth. In addition, there is a set of 43 adjustable ecological parameters that can be customised for a particular ecosystem. The model and its parameters are described in detail in Thornton et al. (2002), White et al. (2000), and Thornton (1998). The Biome-BGC model has been extensively tested and validated for North American and European evergreen and deciduous forest, grassland, and mixed ecosystems (Jung et al., 2007; Pietsch et al., 2005; Bond-Lamberty et al., 2005; Wang et al., 2009). There have also been other adaptations of the Biome-BGC model to managed agricultural systems and crops (Hidy et al., 2012; Di Vittorio et al., 2010; Wang et al., 2005) that involve supplementary code and/or that are specific to grasses and crops in other regions. Extension to New Zealand ecosystems and managed pasture systems represents a new application. We adapt the model through parameter adjustments rather than by modifying model code.

We used the Biome-BGC model's built-in C3 grassland mode to simulate our two managed pasture systems: dairy and sheep/beef. While the core model is not currently designed for farm systems or the presence of grazing animals, we can reinterpret or redefine some of the model's ecological parameters and calibrate them to adequately represent grazing and harvest. Specifically, the "annual whole-plant mortality fraction" parameter can be related via a simple algebraic formula to pasture utilisation (the fraction of above-ground biomass production eaten by grazing animals):

whole plant mortality $=\frac{\text { pasture utilisation }}{(1+\text { leaf }: \text { fine } \operatorname{root} \mathrm{C})}$,

where leaf : fine root $\mathrm{C}$ is a model parameter representing the relative allocation of carbon above and below ground. Intuitively, plant mortality increases along with the amount of grass eaten. For the sake of simplicity we have assumed a nationwide fixed level of pasture utility of 0.55 and 0.90 in sheep/beef and dairy pasture systems, respectively. This results in a mortality proportion that is much higher than that of a natural grassland (default is 0.1 ). In the same manner, the removal of meat and milk products from the system is factored into the model's "annual fire mortality fraction" parameter, which describes the proportion of plants that die due to fire each year and that is effectively removed from the ecosystem. Since fire is not normally a significant occurrence in managed pasture, in our model this fraction represents the approximate proportion of nutrients removed from the ecosystem via milk and meat production. We have set dairy systems to have twice the proportion removed (0.2) as sheep/beef (0.1). (The default for grassland is 0.1 .)

We have also included the combined effects of managed fertiliser application and fertility-driven nitrogen fixation through the model's site-specific nitrogen fixation input parameter. The symbiotic and asymbiotic nitrogen fixation rate is typically of the order of $10^{-4} \mathrm{kgN} \mathrm{m}^{-2}$ year $^{-1}$ for most naturally occurring ecosystems. To represent fixation under high $\mathrm{P}$ fertilisation regimes and urea or other $\mathrm{N}$ additions common in New Zealand dairy farming, we have set this rate much higher, of the order of $10^{-2}$. In our parameterisation, dairy systems have twice the rate of $\mathrm{N}$ input via fixation and fertilisation $\left(0.032 \mathrm{kgN} \mathrm{m}^{-2}\right.$ year $\left.^{-1}\right)$ as sheep/beef $\left(0.018 \mathrm{kgN} \mathrm{m}^{-2}\right.$ year $\left.^{-1}\right)$.

\subsection{LURNZ model}

To develop an estimate of actual total national pasture productivity, we combined information from the Land Use in Rural New Zealand (LURNZ) model v2 with the pasture production outputs from the Biome-BGC model. The LURNZ model (Hendy et al., 2007, 2008; Timar, 2011; Kerr et al., 2012) was developed to explain and simulate changes in four major rural land-use types in New Zealand: dairy, sheep and beef, plantation forestry and regenerating natural forest (henceforth termed scrubland). LURNZ models land use both dynamically, based on national time-series econometric estimates of land-use change, and spatially, based on crosssectional observations of biophysical and socio-economic land attributes. Of most relevance to modelling future pasture production is the ability of LURNZ to evaluate any scenario that can be expressed as a commodity price change in one of the four sectors. The model provides a baseline of actual land use in 2008 and scenario projections for changes to land use in 2020 and 2050 in response to an imposed price 
on carbon (and agricultural $\mathrm{CH}_{4}$ and $\mathrm{N}_{2} \mathrm{O}$ emissions, converted to $\mathrm{CO}_{2}$ equivalent terms). In the climate change scenarios that follow, our dairy and sheep/beef regional breakdown and total national estimates are based on the LURNZ model's observed land-use distribution in 2008, and land-use scenarios are based on projected dynamic change in dairy and sheep/beef land uses in 2020 and 2050.

\subsection{Climate and input data sets}

The New Zealand National Institute of Water and Atmospheric Research (NIWA) Virtual Climate Station Network (VCSN) provides the daily weather input required by the Biome-BGC model. The VCSN is a set of virtual "weather stations" that uses interpolation techniques to provide detailed weather information at each point on $0.05^{\circ}$ grid covering all of New Zealand, approximately $5 \times 5 \mathrm{~km}$ resolution (Tait et al., 2006). Daily weather data are available for each grid cell from 1972 to the present. Direct and indirect inputs to the model from the network include maximum and minimum temperature, precipitation, solar radiation, relative humidity, vapour pressure deficit, and wind run (available from 1997). Before running each model scenario, the model is first "spun up" by recycling the input data sets as many times as necessary for the model to reach a steady state over $\sim 1000$ 2000 years (Thornton and Rosenbloom, 2005).

Future climate change scenarios circa 2050 and 2100 were statistically downscaled to the VCSN using three global climate models (GCMs) from the IPCC Fourth Assessment Report (AR4): giss-eh (NASA/Goddard Institute for Space Shuttles, USA, rererred to as "GIEH"), mpi_echam5 (from the Max Planck Institute in Germany, referred to as "MPI") and cccma_cgcm3_1 (from the Canadian Climate Centre, referred to as "CCC"). This input nominally refers to the 9year period from 2046 to 2054 and the 15-year period from 2097 to 2111, although it is meant to represent an approximate time frame of 50 and 100 years from the present day. Further explanation of these scenarios is in Sect. 3 (see also Renwick et al., 2013; Baisden et al., 2010).

Although the Biome-BGC model does not have an explicit mechanism to incorporate daily wind speed, wind does have a significant evaporative effect on pasture growth in many New Zealand regions. We account for the role of wind in enhancing water loss from pastures by correcting the daily water vapour pressure deficit (VPD) input data with the predicted FAO Penman-Monteith effect of wind on evapotranspiration for grasslands. This effect is particularly important where hot, dry northwesterly winds enhance seasonal drought in the hill country and plains of New Zealand's east coast regions. The modified VPD (which becomes the direct daily VPD input to the model) is calculated from the following equation for evapotranspiration (Allen et al., 1998):
$\mathrm{ET}_{\mathrm{o}}=0.408 \cdot \Delta\left(R_{\mathrm{n}}-G\right)+\frac{\gamma\left(\frac{900}{T+273}\right) u_{2}\left(e_{\mathrm{s}}-e_{\mathrm{a}}\right)}{\Delta+\gamma\left(1+0.34 u_{2}\right)}$,

where $\mathrm{ET}_{\mathrm{o}}$ is reference evapotranspiration $\left(\mathrm{mm} \mathrm{day}^{-1}\right), R_{\mathrm{n}}$ the net radiation at the crop surface $\left(\mathrm{MJ} \mathrm{m}^{-2} \mathrm{day}^{-1}\right), G$ the soil heat flux density $\left(\mathrm{MJ} \mathrm{m}^{-2} \mathrm{day}^{-1}\right), T$ the mean daily air temperature at $2 \mathrm{~m}$ height $\left({ }^{\circ} \mathrm{C}\right), u_{2}$ the wind speed at $2 \mathrm{~m}$ height $\left(\mathrm{m} \mathrm{s}^{-1}\right), e_{\mathrm{s}}$ the saturation vapour pressure $(\mathrm{kPa}), e_{\mathrm{a}}$ the actual vapour pressure $(\mathrm{kPa}),\left(e_{\mathrm{s}}-e_{\mathrm{a}}\right)$ the saturation vapour pressure deficit $(\mathrm{kPa}), \Delta$ the slope vapour pressure curve $\left(\mathrm{kPa}^{\circ} \mathrm{C}^{-1}\right)$, and $\gamma$ is the psychrometric constant $\left(\mathrm{kPa}^{\circ} \mathrm{C}^{-1}\right)$. For our purposes, we take $G=0$ and $\gamma=0.054$, and $\Delta$ is the following:

$\Delta=2503.06 \frac{\exp \left(\frac{17.27 T}{237.3+T}\right)}{(237.3+T)^{2}}$,

where $T$ is again the mean daily air temperature.

The required soil texture and effective rooting depth for each site was obtained from the New Zealand Fundamental Soil Layers (FSL) data set (Landcare Research, 2014), which contains spatial information for 16 soil attributes, including soil texture classes. The soil texture classes were matched to the percentages of sand, silt and clay required by the model by visually identifying modal soil textures present in the National Soils Database.

National and regional pasture production is given in terms of both kilograms of dry matter per hectare and metabolisable energy (MJ per kg dry matter). Remote sensing, augmented by on-the-ground calibration, was used to estimate the seasonal metabolisable energy for all sites from model output.

\subsection{Model calibration and validation}

To adapt the Biome-BGC model for intensive pastoral agriculture, we adjusted key ecological parameters to optimise model output to measured pasture growth data in selected locations across New Zealand. Treating sheep/beef and dairy pasture systems as two different "biomes", we developed a unique parameterisation for each type of system. We used an automated parameter estimation software package, PEST v12.0 (Doherty, 2005), which employs the Gauss-Marquardt-Levenberg inversion method to optimise a model's output to user-supplied observation data. We fit the model's net primary production (NPP) output to historical pasture clipping data from six sites spread temporally and geographically across New Zealand (three dairy and three sheep/beef). Pasture data are typically reported in units of dry matter (DM); NPP can be converted to the equivalent amount of dry matter with the following:

$\mathrm{DM}=2.0 \cdot\left(\frac{r_{\mathrm{ab}}}{r_{\mathrm{ab}}+1}\right) \cdot \mathrm{NPP}$, 
where $r_{\mathrm{ab}}$ is the ratio of above-ground to below-ground allocation (given by the inverse of the new fine root $C$ : new leaf $\mathrm{C}$ allocation parameter in the Biome-BGC model).

Calibration sites are depicted in Fig. 1 and additional detail about the sites is in Table 1. Pasture growth data at the three dairy calibration sites were obtained from Landcorp Farming (C. Isaacs, personal communication, 2011) and publicly available data from DairyNZ (DairyNZ, 2011) and Lincoln University Dairy Farm (South Island Dairying Development Centre, 2014). Data at the three sheep/beef sites were obtained from Beef + Lamb New Zealand (Clarke-Hill and Fraser, 2007) and previously published articles (Rosser and Ross, 2011; Smith et al., 2012). Data consist of monthly, biweekly, or weekly measurements of pasture clippings over a period of at least 2 continuous years and up to 7 years in the case of Winchmore Research Station in Canterbury. These sites were chosen on the basis of geographic location and data availability; we attempted to balance the desire to include a range of climates and regions in New Zealand with the need for high-quality and complete data sets. All data used for calibration were taken from non-irrigated pasture, with the exception of Lincoln University Dairy Farm (in this case irrigation was also simulated in the model during calibration by adding additional precipitation to the meteorological data input file when soil moisture deficit was above a threshold). The site at Te Whanga in the Wairarapa region provides three different data sets from hillside landslide scars of varying ages: a slip that occurred in 1961, a slip in 1977, and one uneroded location. This site is useful for model calibration because recent scars have shallower soils, resulting in lower water storage capacity, thus providing pasture production records under identical climate but varying soil properties (Rosser and Ross, 2011). The Biome-BGC rooting depth parameter is adjusted according to scar age, providing a way to calibrate the model against topsoil depth.

The parameterisation produced a good fit between model output and the observed annual mean production and seasonal cycle of pasture growth. Comparing daily average growth rates over each observation period, the correlation coefficient $R^{2}$ for all dairy and sheep/beef sites is 0.64 and 0.70 , respectively. Figure 2 displays the pasture clipping data and the optimised model fit for each of the calibration sites on a temporal scale. Figure 3 shows a direct comparison of observed and modelled data from all dairy (left) and sheep/beef (right) sites. Figure 3 also reports major axis regression statistics performed by the lmodel 2 v1.7-2 package in R v3.0.2 (Legendre, 2014; R Core Team, 2013) to quantify the model-data relationship. A full list of adjusted and default parameters is in Appendix A.

To validate the sheep/beef model, we chose an additional 22 sites with pasture clipping data (Clarke-Hill and Fraser, 2007) over a similar time period (2003-2005), selected for data completeness and geographical spread. Figure 1 shows the locations of the validation sites. Overall correlation $R^{2}$ for these sites when comparing individual

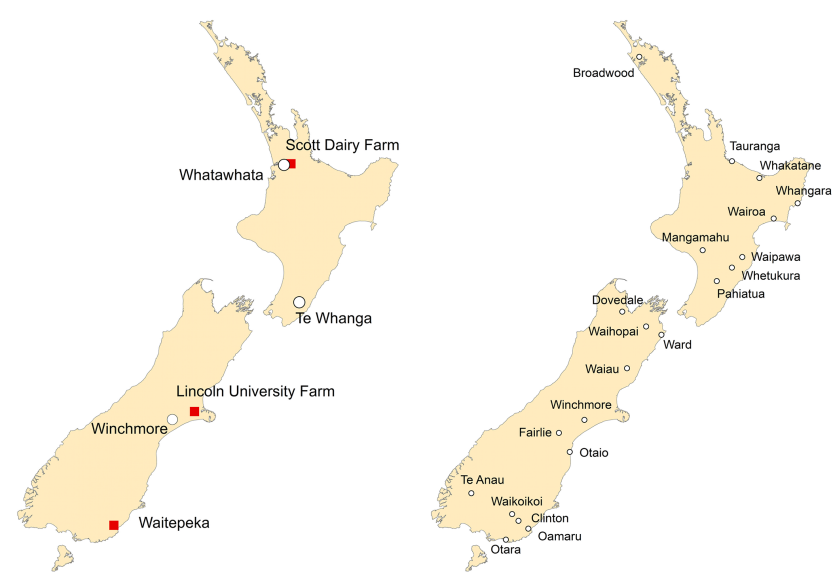

Figure 1. Calibration and validation sites. Left: dairy and sheep/beef calibration sites. White circles are sheep/beef sites, and red squares are dairy sites. Right: sheep/beef validation sites. The three most northern sites (Broadwood, Tauranga, and Whakatane) are outliers in terms of model-observation fit.

measurement intervals is 0.36 . The scatter plot shown in Fig. 4 reveals that the model is biased low at higher values, often underestimating the observed peaks in production in spring and summer. The three northernmost sites (Broadwood, Tauranga, and Whakatane) perform very poorly, possibly because the climate is warmer than the rest of New Zealand and $\mathrm{C} 4$ grasses (rather than C3) are common. Removing these sites, $R^{2}$ rises to 0.41 . There is also significant variation in pasture age, hill slope, fertilisation and nutrient content among individual sites that are not included in our model and could account for the large difference in model fit at specific locations. Monthly averages over several years generally compare better to observations (Fig. 4), but there is still a bias during spring and summer months. The correlation coefficient $R^{2}$ for monthly averages aggregated over 3 years of pasture clipping data for all validation sites is 0.48 , and without the three northern sites is 0.59 . The relationship between the model and measurements in Fig. 4 is quantified with major axis regression statistics using the same methodology as in Fig. 3.

For the dairy model, no additional spatially varying data were available for validation at the time of our study. Consequently, we use national milk production data as a proxy for pasture growth and an evaluation of model performance. In a separate report, we examined the relation between modelled pasture production and total national milk solids production data for New Zealand (Keller, 2012), finding excellent correlation in the 6 years from June 2006 to May 2012 (annual milk season in New Zealand runs from June to May) and moderate correlation over the last 15 years $\left(R^{2}=0.86\right.$ and 0.46 , respectively). Although indirect, this demonstrated relation to actual milk production data allows us to have reasonable confidence in the national model output. 
Table 1. Calibration sites, location, description and dates of pasture growth data used for model calibration.

\begin{tabular}{|c|c|c|c|c|c|}
\hline Site & Location & Description & Data availability & $\begin{array}{l}\text { Mean annual } \\
\text { rainfall }(\mathrm{mm})\end{array}$ & $\begin{array}{l}\text { Mean daily } \\
\max / \min \\
\text { temperature }\left({ }^{\circ} \mathrm{C}\right)\end{array}$ \\
\hline Whatawhata & $\begin{array}{l}-37.80^{\circ} \mathrm{S} \\
175.15^{\circ} \mathrm{E} \\
\text { Waikato }\end{array}$ & Sheep/beef, easy hills & $\begin{array}{l}\text { Jan 2003-Sep } 2005 \text { monthly } \\
\text { intervals }\end{array}$ & 1607 & $19 / 9.6$ \\
\hline Te Whanga Station & $\begin{array}{l}-41.03^{\circ} \mathrm{S} \\
175.74^{\circ} \mathrm{E} \\
\text { Wairarapa }\end{array}$ & $\begin{array}{l}\text { Sheep/beef, hillside } \\
\text { landslide scars }\end{array}$ & $\begin{array}{l}\text { Jun 2007-Aug } 2009 \\
\text { 2-month intervals (three dis- } \\
\text { tinct sites) }\end{array}$ & 886 & $18 / 7.4$ \\
\hline $\begin{array}{l}\text { Winchmore Irrigation } \\
\text { Research Station }\end{array}$ & $\begin{array}{l}-43.83^{\circ} \mathrm{S} \\
171.71^{\circ} \mathrm{E} \\
\text { Canterbury }\end{array}$ & Sheep/beef, flat & $\begin{array}{l}\text { Jan 1997-Dec } 2003 \text { monthly } \\
\text { intervals }\end{array}$ & 715 & $17 / 5.7$ \\
\hline DairyNZ Scott Farm & $\begin{array}{l}-37.77^{\circ} \mathrm{S} \\
175.36^{\circ} \mathrm{E} \\
\text { Hamilton }\end{array}$ & $\begin{array}{l}\text { Dairy, large-scale farm } \\
\text { system trials }\end{array}$ & $\begin{array}{l}\text { Aug 2009-May } 2011 \text { weekly } \\
\text { intervals }\end{array}$ & 1086 & $19 / 8.8$ \\
\hline $\begin{array}{l}\text { Lincoln University } \\
\text { Dairy Farm (LUDF) }\end{array}$ & $\begin{array}{l}-43.64^{\circ} \mathrm{S} \\
172.44^{\circ} \mathrm{E} \\
\text { Canterbury }\end{array}$ & Dairy, irrigated & $\begin{array}{l}\text { Jan 2005-Dec } 2009 \text { weekly } \\
\text { intervals }\end{array}$ & 604 & $17 / 6.8$ \\
\hline $\begin{array}{l}\text { Landcorp Waitepeka } \\
\text { Dairy Farm }\end{array}$ & $\begin{array}{l}-46.29^{\circ} \mathrm{S} \\
169.67^{\circ} \mathrm{E} \\
\text { Southland }\end{array}$ & Dairy & $\begin{array}{l}\text { Jan 2004-Dec } 2009 \text { monthly } \\
\text { intervals }\end{array}$ & 701 & $15 / 5.7$ \\
\hline
\end{tabular}

We focus primarily on seasonal and annual averages at a national level in this study. In addition, because we are evaluating future scenarios relative to the baseline and are not concerned with absolute levels of production, our subsequent analysis is minimally affected by model bias.

\subsection{Methodology and model scenarios}

We introduce DLUCS methodology to construct and analyse model scenarios: we simulate biophysical conditions affecting grass growth with the Biome-BGC model to produce an estimate of pasture production at all locations on the national grid, then sample selectively according to the specific land use or economic situation modelled with LURNZ. Scenarios can be anything that can be modelled through changes in weather or nutrient input and/or economic drivers of landuse change. Land use is decoupled from the biophysical dynamics of plant growth, and the two are integrated at the final stage. By creating a national production data set with BiomeBGC and then re-sampling it using the output from LURNZ, we are able to quickly examine many different plausible land use and economic scenarios relevant for policy decisions, including the response to climate change.

Scenarios for this project were developed in consultation with the New Zealand Ministry for Primary Industries (MPI) and reflect factors that are assumed to have significant impact on pasture productivity in New Zealand. All scenarios are constructed to represent averages over 9-year periods centred on 2005,2020 , or 2050 and, in the case of climate change in 2100, the 15-year period from 2097 to 2111 . We run the model for each type of pasture for all grid cells, regardless of actual land use; results are mapped for dairy and sheep/beef systems as if all available land (exclusive of conservation land, water, year-round ice cover and urban areas) were devoted to that system. We then calculate regional and national pasture production totals by summing production from each grid cell categorised as either dairy or sheep/beef in LURNZ. Spatial mapping and production summation were performed using ArcGIS 9.3 (ESRI, 2009). With the exception of the land-use change scenarios, all land-use categorisations are derived from the LURNZ model's 2008 map, based on actual data, and stay constant at 2008 levels in climate and intensification scenarios at 2020, 2050 and 2100 in order to keep the effects of land-use change separate from the other effects that we simulate. The scenarios chosen are intended, as much as possible, to isolate a single effect, so that the sensitivity of pasture production to that particular effect alone can be estimated relative to the baseline. However, we note that some scenarios are closely linked, and in practice it might not be realistic to consider each one in isolation. We describe each scenario in detail in the following sections.

\subsubsection{Baseline}

The baseline scenario is the output from the Biome-BGC model run using actual climate data from the VCSN for 2001-2009, averaged over the 9 years. This scenario is intended to represent "present-day" climate and to serve as a 

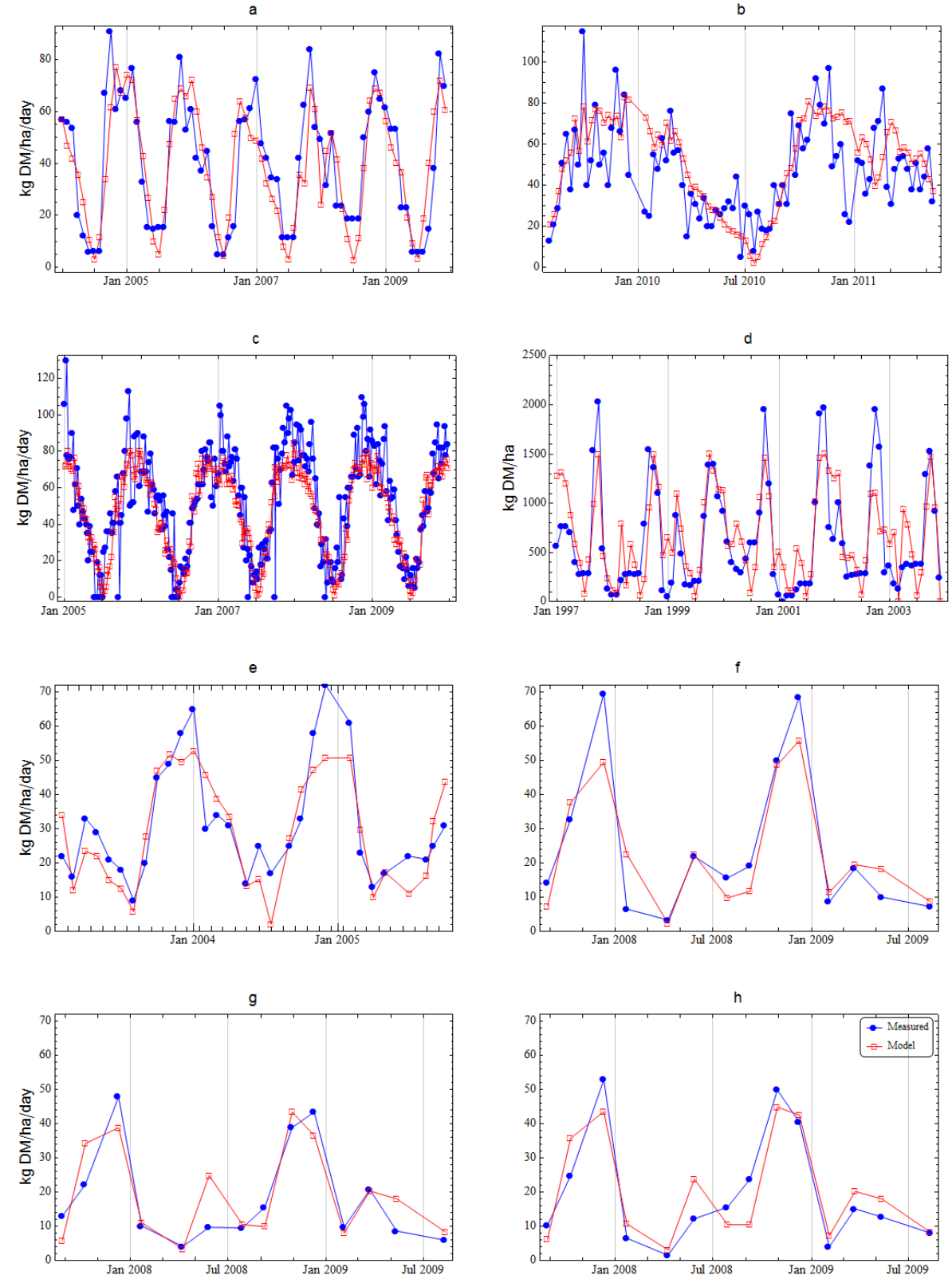

Figure 2. Modelled and measured pasture growth at calibration sites. Growth (in average kilograms of dry matter per hectare per day) versus time at all dairy (a-c) and sheep/beef (d-h) calibration sites: (a) Waitepeka Dairy Farm (Southland) from January 2004 to December 2009 ; (b) Scott Dairy Farm (Hamilton) from August 2009 to May 2011; (c) Lincoln University Dairy Farm (Canterbury) from January 2005 to December 2009; (d) Winchmore Research Station (Canterbury) from January 1997 to December 2003 (in total kilograms of dry matter per hectare rather than daily averages); (e) Whatawhata (Waikato) from February 2003 to October 2005; (f) Te Whanga (Wairarapa) uneroded site, (g) Te Whanga 1977 slip site, and (h) Te Whanga 1961 slip site, from August 2007 to August 2009.

Table 2. Comparison of baseline and intensification Biome-BGC model parameters.

\begin{tabular}{lllll}
\hline Parameter & Baseline sheep/beef & Intense sheep/beef & Baseline dairy & Intense dairy \\
\hline Pasture utilisation & 0.55 & 0.60 & 0.90 & 0.95 \\
Annual whole plant mortality fraction & 0.226 & 0.247 & 0.722 & 0.762 \\
Symbiotic \& asymbiotic nitrogen fixation $\left(\mathrm{kgN} \mathrm{m}^{-2} \mathrm{year}^{-1}\right)$ & 0.018 & 0.021 & 0.032 & 0.038 \\
\hline
\end{tabular}



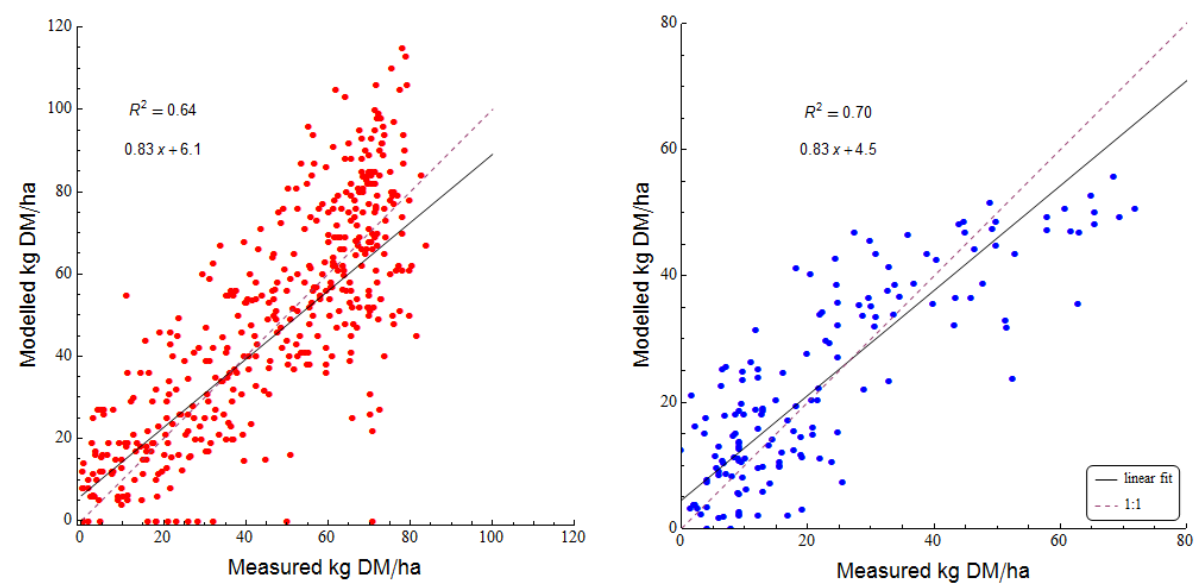

Figure 3. Scatter plot of modelled vs. measured pasture growth for calibration sites. Measured and modelled daily growth rates (kilograms of dry matter per hectare) from all calibrations sites for dairy (left) and sheep/beef (right). Data are daily averages of growth over cutting intervals (between 1 week and 1 month). Correlation coefficient $R^{2}=0.64$ (RMSE $=16.6$ ) for dairy and $0.70(\mathrm{RMSE}=9.88)$ for sheep/beef. Type 2 linear regression model shown is $y=0.83 \pm 0.060 x+6.1 \pm 2.9$ (dairy) and $y=0.83 \pm 0.090 x+6.1 \pm 2.0$ (sheep/beef). Reported errors are $2 \sigma$. The $1: 1$ line is drawn for reference.
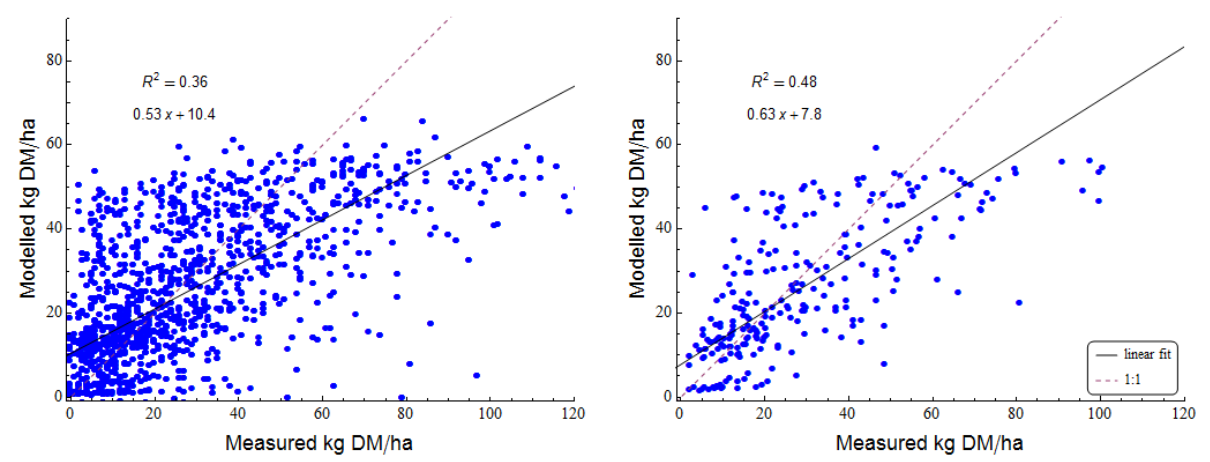

Figure 4. Scatter plot of modelled vs. measured pasture growth for validation sites. Measured and modelled daily growth rates (kilograms of dry matter per hectare) for all sheep/beef validation sites compared at individual cutting intervals (left) and monthly averages over 3 years (right). Correlation coefficient $R^{2}=0.36(\mathrm{RMSE}=20.9)$ and $0.48(\mathrm{RMSE}=15.9)$, respectively. Type 2 linear regression model shown is $y=0.53 \pm 0.040 x+10.4 \pm 1.2$ (left) and $y=0.63 \pm 0.085 x+7.8 \pm 2.5$ (right). Reported errors are $2 \sigma$. The $1: 1$ line is drawn for reference.

benchmark for comparisons to scenarios in 2020 and 2050. The baseline that is used as comparison for the 2100 climate change scenarios is slightly different, covering the 15 years from 1997 to 2011, to correspond to the timing and length of the 2100 simulations. The small inconsistency in the baselines does not alter the general trend in the final results and was chosen to ensure matching with the statistically downscaled climate data sets and a sensible averaging period for the scenarios studied.

\subsubsection{Land use}

We simulated dynamic land-use changes using the LURNZ model by assuming the primary drivers behind land-use change are economic factors that influence the monetary returns to land under different uses. We selected three scenarios focused on the importance and associated uncertainties of the phase-in of emissions trading, corresponding to low, best guess and high carbon prices (NZD 0, 50 and 100 per tonne $\mathrm{CO}_{2 \mathrm{e}}$, respectively) under the New Zealand Emissions Trading Scheme (ETS). Land-use projections are provided for 2020 and 2050 and subsequently combined with baseline dairy and sheep/beef pasture production.

Along with land-use change, intensification of current usage is also likely to be a considerable driver of pasture production over the coming decades in the absence of new environmental regulation (Parfitt et al., 2006, 2008). To simulate a representative "intensification" scenario in 2020 with Biome-BGC, we increased the nitrogen fixation levels per hectare and the effective utilisation of pasture nationwide. Parameter values used in the baseline and intensification scenarios are compared in Table 2. Intensification here is based on high nutrient inputs that represent roughly what a farmer would do in a 10-year time frame in response to long-term 


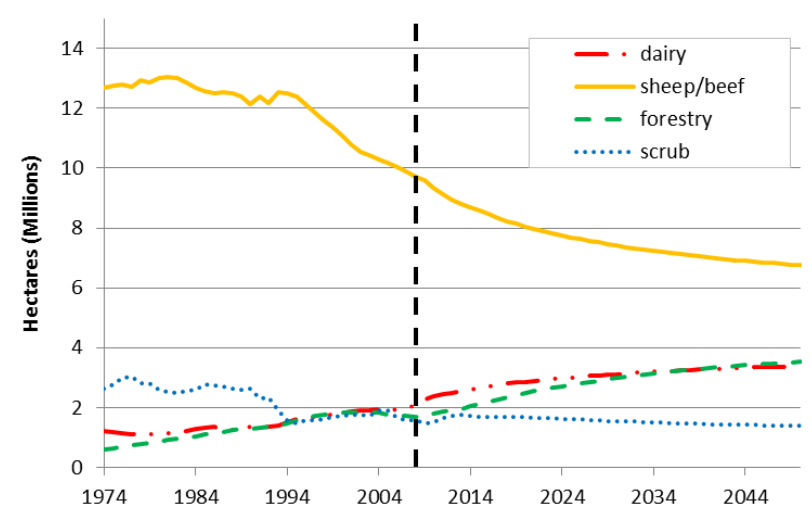

Figure 5. Historical and projected land-use areas in New Zealand (carbon price $=$ NZD 0). Data to the left of the dashed line (2008) are historical, and to the right are estimated by LURNZ based on exogenous forecasts of economic variables.

increases in commodity prices (near doubling). Climate was held constant at present-day inputs, and $\mathrm{CO}_{2}$ concentrations are increased according to the A2 scenario from the IPCC Special Report on Emissions Scenarios (SRES; Nakicenovic and Swart, 2000). The combined effects of $\mathrm{CO}_{2}$ fertilisation and intensification were modelled together in this case to test for strong non-additive interactions between elevated $\mathrm{CO}_{2}$ and agricultural $\mathrm{N}$ cycling.

\subsubsection{Climate change}

The climate change scenarios we selected provide mid-range and upper-end estimates for the combined impact of climate change and elevated $\mathrm{CO}_{2}$ on pasture growth circa 2050 and 2100. Scenarios were chosen from the ensemble of IPCC AR4 GCM simulations. The particular models that were chosen are in good agreement with present-day climate in the New Zealand region but forecast significantly different changes in local patterns of precipitation and temperature by 2100. A more complete description of the projected changes for New Zealand and the range of responses in selected AR4 GCMs is in Renwick et al. (2013). Climate projections for New Zealand are based on a downscaling scheme that uses partial least squares regression to statistically downscale rainfall, temperature, and solar radiation from GCMs directly to the VCSN (Clark et al., 2011).

The SRES A2 emissions scenario is used to estimate the increase in $\mathrm{CO}_{2}$ concentration levels in the atmosphere for all climate change scenarios. This scenario results in approximately $4{ }^{\circ} \mathrm{C}$ of global mean average temperature increase by 2100 (measured since pre-industrial times, nominally 1750). A2 is suitable as a mid-range projection in the shorter term out to 2050. In longer-range climate change projections, it represents an upper-end scenario, which becomes the case by 2080. Atmospheric concentrations start at $375 \mathrm{ppm}$ in 2005 and rise to $827.3 \mathrm{ppm}$ in 2099 (Nakicenovic and Swart, 2000; ENSEMBLES, 2009). This scenario is increasingly regarded

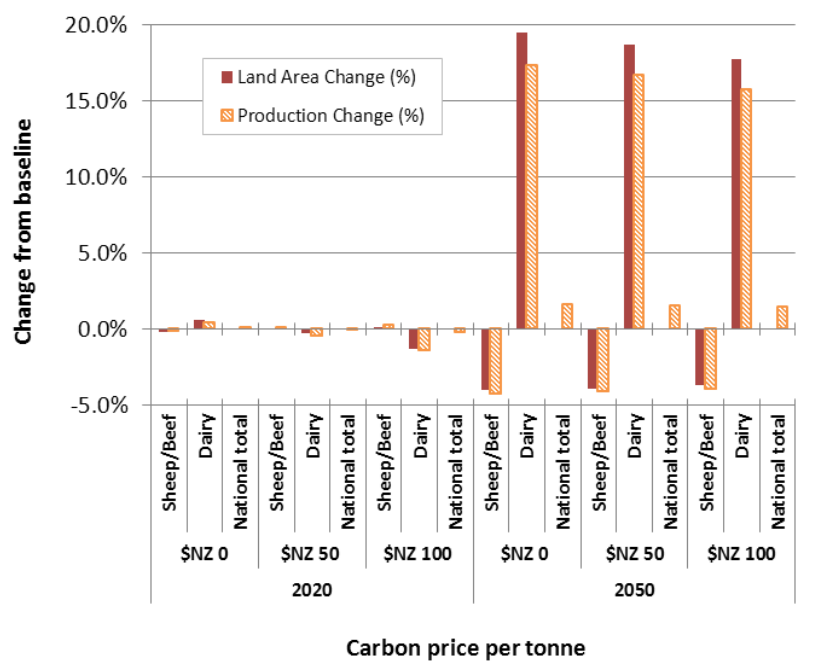

Figure 6. Land area and pasture production changes. Percentage change from baseline estimated by combining outputs of LURNZ and Biome-BGC models in 2020 and 2050.

as more likely since recent emissions have closely tracked its projections.

We first examined the effect of $\mathrm{CO}_{2}$ fertilisation alone on pasture production, keeping climate patterns the same as the baseline but increasing atmospheric $\mathrm{CO}_{2}$ concentrations according to the A2 scenario. This is referred to as "elevated $\mathrm{CO}_{2}$ ". This scenario was evaluated on the short time frame of 2020 to provide a partial derivative of elevated $\mathrm{CO}_{2}$ effects on a timescale during which the effects of climate change might remain within the bounds of regional and decadal variability (e.g. Deser et al., 2012).

The climate data for our 2050 mid-range scenario have been downscaled from one GCM, MPI, and broadly represent a "mid-range" projection for the time slice 2045-2055. The upper-end scenario represents the high end of temperature response and, for most of the country, provides a sample of a severe rainfall reduction across all 19 GCMs. Climatic input data for this scenario were provided by downscaled simulations from GIEH.

The two scenarios provided for 2100 (Renwick et al., 2013) use downscaled simulations from the MPI and CCC models and also represent "mid-range" and "upper-end" projections. These models predict an annual mean temperature change in 2090 for New Zealand of 3.0 and $3.9^{\circ} \mathrm{C}$, respectively (relative to 1990). Simulations were run for the nominal years 2097-2111 but are meant to represent general climate in approximately 100 years. These were compared to a present-day baseline scenario covering the period 19972011.

Apart from climate and atmospheric $\mathrm{CO}_{2}$ concentrations, other parameters remained unchanged, thus providing an understanding of possible effects of climate change with little change in agronomic systems. 


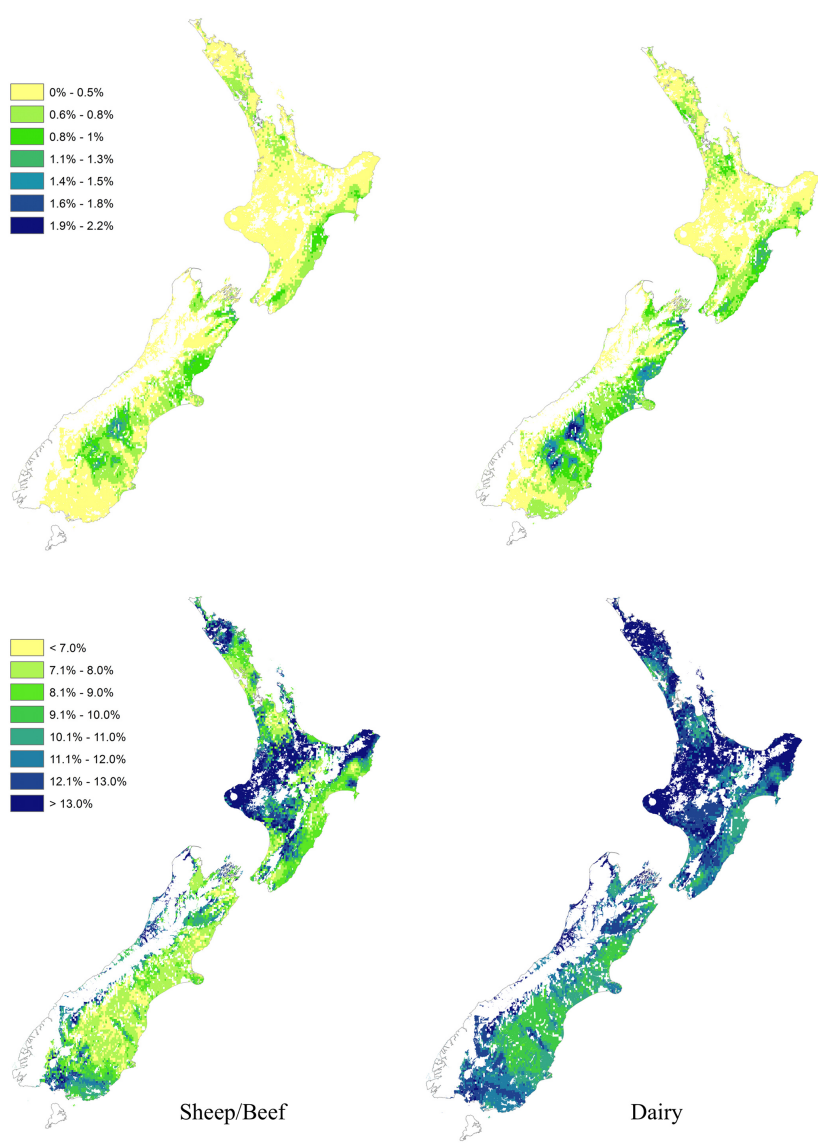

Figure 7. Elevated $\mathrm{CO}_{2}$ (top) and intensification (bottom) 2020 model scenarios, average annual total pasture production, percentage change from baseline for sheep/beef (left) and dairy (right). Each map shows national pasture production as if all of the available land (excluding urban and conservation land) were devoted to sheep/beef or dairy agriculture systems and is not an actual representation of current or projected land use.

\section{Results and discussion}

\subsection{Results}

Results from Biome-BGC and LURNZ for selected scenarios are shown in Tables 3 and 4 and Figs. 6-9. We map production results from Biome-BGC across all of New Zealand, then combine with land uses from LURNZ according to the scenario and tabulate totals nationally. Appendix B contains more detailed results tabulated by region and season.

Our scenario results are reported relative to the baseline scenario to limit the impact of potential biases in the model. The model estimates have absolute uncertainty that has not been determined, and we therefore emphasise that results are expected to be most robust in terms of comparisons between model scenarios. We show here the percentage difference in average annual pasture production for each scenario, as compared to the baseline.
With the baseline model, we calculate that New Zealand's average annual pasture production is approximately 800 to 900 petajoules (PJ) of metabolisable energy available to grazing animals. This number is consistent with the estimates used to compile New Zealand's most recent UNFCCC emissions inventories, which was 970 PJ in 2011 (New Zealand Ministry for the Environment, 2009, 2013).

Land-use change projections from all three modelled carbon price scenarios suggest that, in general, economic factors other than carbon price dominate. Therefore, the current trends in land-use change continue irrespective of carbon price: dairy is expanding, and sheep/beef is contracting over time. Figure 5 shows historical land area under each of the four land-use categories in LURNZ up to and including 2008 and projected future land-use area thereafter, out to 2050 , with no carbon price imposed. Overall, LURNZ model projections indicate that carbon prices have very limited effects on land use, and current land-use change trends will continue. However, these trends by themselves can be expected to have a significant effect on New Zealand's pasture production, particularly through an 18-19\% expansion of dairy area. Figure 6 summarises LURNZ projections for 2020 and 2050 in terms of percentage change in land area and in pasture production. All land-use scenarios resulted in little change in 2020 relative to the baseline. In 2050, the LURNZ model projected a $4 \%$ decrease in the area of sheep/beef pasture and an 18-19\% increase in the area of dairy pasture, regardless of carbon price. Pasture production changes were proportional to area changes. At 2050, the sheep/beef decline and dairy expansion nearly offset one another, resulting in a small net increase of $1.5 \%$ in total national pasture production.

Under elevated atmospheric $\mathrm{CO}_{2}$ concentrations in 2020 (Fig. 7), very small increases in production of the order of $\sim 0.5 \%$ were projected, which can be compared to a $10 \%$ increase over present-day $\mathrm{CO}_{2}$ concentration levels. (The $\mathrm{A} 2$ emissions scenario contains a $37 \%$ increase in $\mathrm{CO}_{2}$ concentration levels in 2050 and a $94 \%$ increase by 2100 .) The increase in production from enhanced $\mathrm{CO}_{2}$ was slightly greater for dairy systems. No region recorded a loss of production, while the largest regional increases were of the order of $1 \%$.

Results from the intensification scenario (Fig. 7) indicate potential increases in pasture production of $10 \%$ nationally by 2020 . Results ranged between 8 and $14 \%$ in different regions. Overall, dairy systems showed about $2-3 \%$ more of an increase than sheep/beef systems. When compared to the results due to elevated $\mathrm{CO}_{2}$ alone, the results imply the majority of production increases can be attributed to the change in model parameters due to intensification, with elevated $\mathrm{CO}_{2}$ explaining only a small portion, $0.5 \%$.

The modelled climate change scenarios in 2050 suggest relatively small changes at a national scale but potentially more significant regional effects. Results (Fig. 8) suggest a $2 \%$ increase in total national production in 2050 for the mid-range MPI scenario and a $1 \%$ increase for the 
Table 3. Summary of model scenario results with constant land-use area, tabulated by scenario and season. Percent change calculated in reference to the baseline scenario. Seasonal numbers are averages over the modelled time slice, and national totals are the annual average sum of sheep/beef and dairy results. ME is metabolisable energy, defined as the amount of energy available to grazing animals.

\begin{tabular}{|c|c|c|c|c|c|c|c|c|}
\hline \multirow[b]{2}{*}{ Scenario } & \multirow{2}{*}{$\begin{array}{l}\text { Area } \\
(\mathrm{kha})\end{array}$} & Winter & Spring & Summer & Autumn & \multirow[b]{2}{*}{ Average } & \multirow{2}{*}{$\begin{array}{r}\text { Total ME } \\
(\mathrm{TJ})\end{array}$} & \multirow{2}{*}{$\begin{array}{r}\text { Chang } \\
(\%\end{array}$} \\
\hline & & \multicolumn{4}{|c|}{ Average production $\left(\mathrm{MJ} \mathrm{ha}^{-1} \mathrm{~d}^{-1}\right)$} & & & \\
\hline \multicolumn{9}{|c|}{ Baseline 2001-2009 } \\
\hline Sheep \& beef & 7778 & 73 & 356 & 279 & 159 & 217 & 615126 & - \\
\hline Dairy & 1557 & 163 & 594 & 515 & 353 & 406 & 231014 & - \\
\hline National total & 9335 & & & & & & 846140 & - \\
\hline \multicolumn{9}{|c|}{ Elevated $\mathrm{CO}_{2} 2020$} \\
\hline Sheep \& beef & 7778 & 74 & 356 & 280 & 160 & 218 & 617531 & $0.4 \%$ \\
\hline Dairy & 1557 & 166 & 598 & 517 & 354 & 409 & 232203 & $0.5 \%$ \\
\hline National total & 9335 & & & & & & 849734 & $0.4 \%$ \\
\hline \multicolumn{9}{|c|}{ Intensification 2020} \\
\hline Sheep \& beef & 7778 & 80 & 396 & 301 & 172 & 237 & 673861 & $9.5 \%$ \\
\hline Dairy & 1557 & 181 & 668 & 581 & 399 & 457 & 259915 & $12.5 \%$ \\
\hline National total & 9335 & & & & & & 933776 & $10.4 \%$ \\
\hline \multicolumn{9}{|c|}{ MPI climate change 2050} \\
\hline Sheep \& beef & 7778 & 80 & 360 & 276 & 168 & 221 & 627293 & $2.0 \%$ \\
\hline Dairy & 1557 & 186 & 617 & 518 & 364 & 421 & 239427 & $3.6 \%$ \\
\hline National total & 9335 & & & & & & 866720 & $2.4 \%$ \\
\hline \multicolumn{9}{|c|}{ GIEH climate change 2050} \\
\hline Sheep \& beef & 7778 & 85 & 354 & 260 & 169 & 217 & 616759 & $0.3 \%$ \\
\hline Dairy & 1557 & 204 & 615 & 498 & 372 & 422 & 239967 & $3.9 \%$ \\
\hline National total & 9335 & & & & & & 856726 & $1.3 \%$ \\
\hline \multicolumn{9}{|c|}{ Baseline 1997-2011 } \\
\hline Sheep \& beef & 7778 & 69 & 350 & 230 & 135 & 196 & 556567 & - \\
\hline Dairy & 1557 & 153 & 588 & 472 & 311 & 381 & 216717 & - \\
\hline National total & 9335 & & & & & & 773284 & - \\
\hline \multicolumn{9}{|c|}{ MPI climate change 2100} \\
\hline Sheep \& beef & 7778 & 97 & 338 & 185 & 143 & 191 & 541710 & $-2.7 \%$ \\
\hline Dairy & 1557 & 235 & 608 & 408 & 336 & 397 & 225631 & $4.1 \%$ \\
\hline National total & 9335 & & & & & & 767341 & $-0.8 \%$ \\
\hline \multicolumn{9}{|c|}{ CCC climate change 2100} \\
\hline Sheep \& beef & 7778 & 105 & 326 & 112 & 139 & 170 & 483402 & $-13.1 \%$ \\
\hline Dairy & 1557 & 258 & 608 & 306 & 331 & 376 & 213593 & $-1.4 \%$ \\
\hline National total & 9335 & & & & & & 696995 & $-9.9 \%$ \\
\hline
\end{tabular}

upper-end GIEH scenario. The dairy model shows slightly larger production increases of about $4 \%$, regardless of scenario. Sheep/beef production appears more sensitive to the difference in the two scenarios, in particular to the more extreme precipitation decreases from GIEH. Sheep/beef production increases by $2 \%$ with the milder MPI scenario but results in virtually no change in GIEH, with the losses in some regions balancing the gains in others. For comparison, we show the corresponding differences in precipitation from both models in Fig. 10. The decrease in sheep/beef production in the east and north in the GIEH scenario closely follows the pattern of decrease in precipitation in these regions. Despite some strong regional effects, however, the model suggests that overall there will not be a large impact on pasture production in 2050 from climate change within expected bounds. Seasonal results (see Appendix B) indicate that in general winter production will increase and summer 
Table 4. Summary of model scenario results with land-use change. Percent change calculated in reference to the baseline scenario in Table 3. Seasonal numbers are averages over the modelled time slice, and national totals are the annual average sum of sheep/beef and dairy results. $\mathrm{ME}$ is metabolisable energy, defined as the amount of energy available to grazing animals.

\begin{tabular}{|c|c|c|c|c|c|c|c|c|c|}
\hline \multirow[b]{2}{*}{ Region } & \multirow{2}{*}{$\begin{array}{l}\text { Area } \\
\text { (kha) }\end{array}$} & \multirow{2}{*}{$\begin{array}{r}\text { Change } \\
(\%)\end{array}$} & Winter & Spring & Summer & Autumn & \multirow[b]{2}{*}{ Average } & \multirow{2}{*}{$\begin{array}{r}\text { Total ME } \\
(\mathrm{TJ})\end{array}$} & \multirow{2}{*}{$\begin{array}{r}\text { Change } \\
(\%)\end{array}$} \\
\hline & & & \multicolumn{4}{|c|}{ Average production $\left(\mathrm{MJ} \mathrm{ha}^{-1} \mathrm{~d}^{-1}\right)$} & & & \\
\hline \multicolumn{10}{|c|}{ Land-use 2020 NZD 0} \\
\hline Sheep \& beef & 7766 & $-0.2 \%$ & 73 & 356 & 279 & 159 & 217 & 614327 & $-0.13 \%$ \\
\hline Dairy & 1566 & $0.6 \%$ & 163 & 595 & 514 & 352 & 406 & 232053 & $0.45 \%$ \\
\hline National total & 9332 & & & & & & & 846380 & $0.03 \%$ \\
\hline \multicolumn{10}{|c|}{ Land-use 2020 NZD 50} \\
\hline Sheep \& beef & 7777 & $0.0 \%$ & 73 & 356 & 279 & 159 & 217 & 615462 & $0.05 \%$ \\
\hline Dairy & 1552 & $-0.3 \%$ & 163 & 595 & 513 & 352 & 406 & 230025 & $-0.43 \%$ \\
\hline National total & 9330 & & & & & & & 845487 & $-0.08 \%$ \\
\hline \multicolumn{10}{|c|}{ Land-use 2020 NZD 100} \\
\hline Sheep \& beef & 7789 & $0.1 \%$ & 73 & 356 & 279 & 159 & 217 & 616684 & $0.25 \%$ \\
\hline Dairy & 1537 & $-1.3 \%$ & 163 & 595 & 513 & 352 & 406 & 227802 & $-1.39 \%$ \\
\hline National total & 9326 & & & & & & & 844486 & $-0.20 \%$ \\
\hline \multicolumn{10}{|c|}{ Land-use 2050 NZD 0} \\
\hline Sheep \& beef & 7465 & $-4.0 \%$ & 73 & 354 & 279 & 159 & 216 & 588911 & $-4.26 \%$ \\
\hline Dairy & 1861 & $19.5 \%$ & 157 & 589 & 506 & 345 & 399 & 271076 & $17.3 \%$ \\
\hline National total & 9326 & & & & & & & 859987 & $1.64 \%$ \\
\hline \multicolumn{10}{|c|}{ Land-use 2050 NZD 50} \\
\hline Sheep \& beef & 7475 & $-3.9 \%$ & 73 & 354 & 279 & 159 & 216 & 589695 & $-4.13 \%$ \\
\hline Dairy & 1848 & $18.7 \%$ & 157 & 589 & 506 & 345 & 399 & 269462 & $16.6 \%$ \\
\hline National total & 9323 & & & & & & & 859157 & $1.54 \%$ \\
\hline \multicolumn{10}{|c|}{ Land-use 2050 NZD 100} \\
\hline Sheep \& beef & 7487 & $-3.7 \%$ & 73 & 354 & 279 & 159 & 216 & 590893 & $-3.94 \%$ \\
\hline Dairy & 1833 & $17.7 \%$ & 157 & 590 & 506 & 345 & 399 & 267232 & $15.7 \%$ \\
\hline National total & 9320 & & & & & & & 858125 & $1.42 \%$ \\
\hline
\end{tabular}

production will decline; spring and autumn production trends vary by region.

Under the two 2100 scenarios, MPI is again associated with milder climate change than is CCC (Fig. 9). Sheep/beef pasture production declines slightly, at around $-3 \%$, and dairy production increases by $4 \%$, resulting in almost no change nationally with current land use. With the CCC model, however, production for both sheep/beef and dairy systems declined, with national sheep/beef production decreasing by $-13 \%$ and dairy decreasing by about $-3 \%$. The decline is especially pronounced in the South Island regions of Canterbury and Otago, where sheep/beef production decreases by -19 and $-15 \%$ and dairy decreases by -8 and $-7 \%$, respectively (see Appendix B). These results are consistent with the patterns of climate change predicted for New Zealand by each climate model, with CCC predicting a larger increase in temperatures and more drastic changes in rainfall (Fig. 10), especially in the spring and summer months when the majority of pasture growth occurs. The eastern regions of the South Island in particular are drier and warmer during these crucial growing seasons.

\subsection{Comparison of climatic and land management factors}

To better understand the effects of inputs and model modifications on the results, we compare the relative significance of selected inputs and parameters in more detail for our case study. Looking at all model results, climatic factors (the primary input to Biome-BGC) are clearly influential in production trends. Land management factors are important as well, but our analysis is limited somewhat by the fact that we have not modelled spatial variation within each land-use subtype.

A general, comprehensive sensitivity analysis of BiomeBGC model parameters has been done by White et al. (2000). The authors found that variations in $\mathrm{C}: \mathrm{N}$ ratio of leaves, 

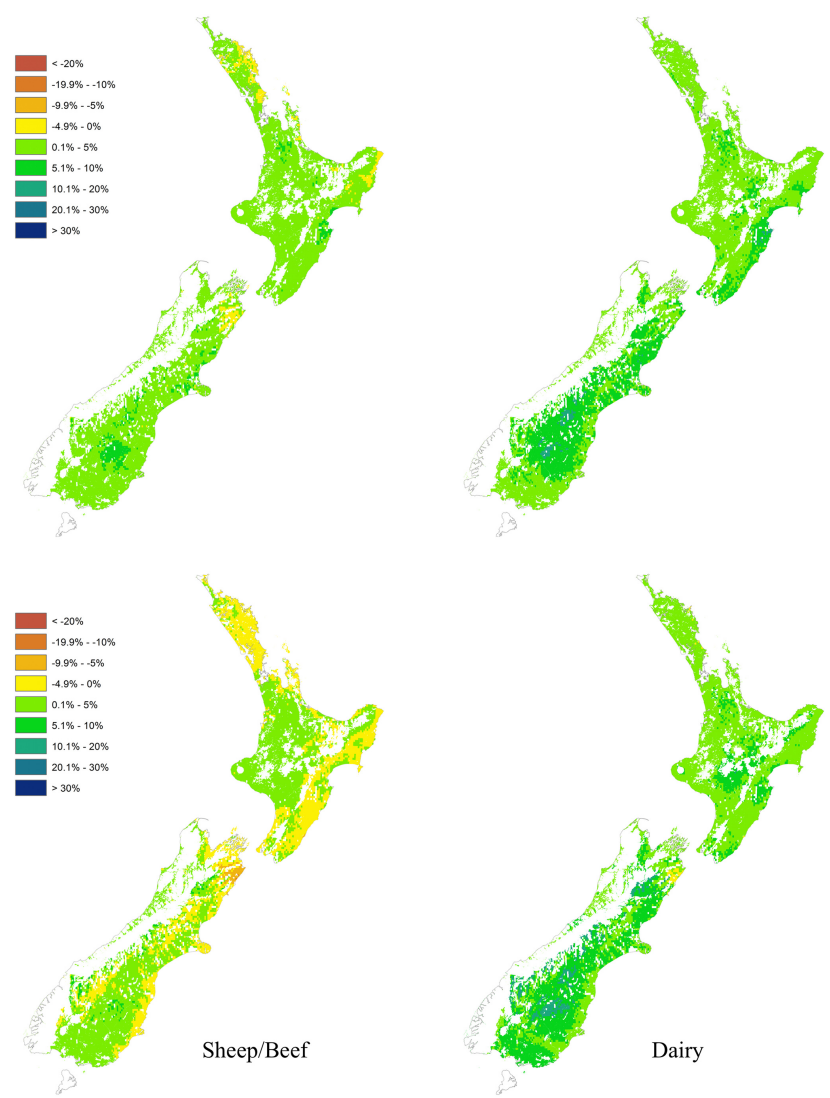

Figure 8. Climate change 2050 MPI (top) and GIEH (bottom) model scenarios, average annual total pasture production, percentage change from baseline for sheep/beef (left) and dairy (right). Each map shows national pasture production as if all of the available land (excluding urban and conservation land) were devoted to sheep/beef or dairy agriculture systems and is not an actual representation of current or projected land use.

fire mortality, and parameters relating to litter quality have the most impact on NPP in grass biomes, leading to the conclusion that productivity is primarily nitrogen-limited in nonwoody biomes. In comparison, our calibration reveals that the most significant effects on NPP in both sheep/beef and dairy systems come from varying two different parameters: the maximum stomatal conductance and the fraction of leaf $\mathrm{N}$ in Rubisco. This suggests that in our model, New Zealand's highly managed grasslands are primarily waterand photosynthesis-limited rather than nitrogen-limited.

The influence of precipitation is especially visible in model results. Changes in pasture production in our climate change scenarios in 2050 and 2100 closely follow the patterns of change in precipitation (Fig. 10). Looking at the upper-end GIEH scenario in 2050, decreases of 5-10\% in precipitation along the east coast of New Zealand correspond to a 2-3\% regional decrease sheep/beef pasture production. Dairy pasture appears less sensitive to changes in precipitation; one explanation for this could be that the higher
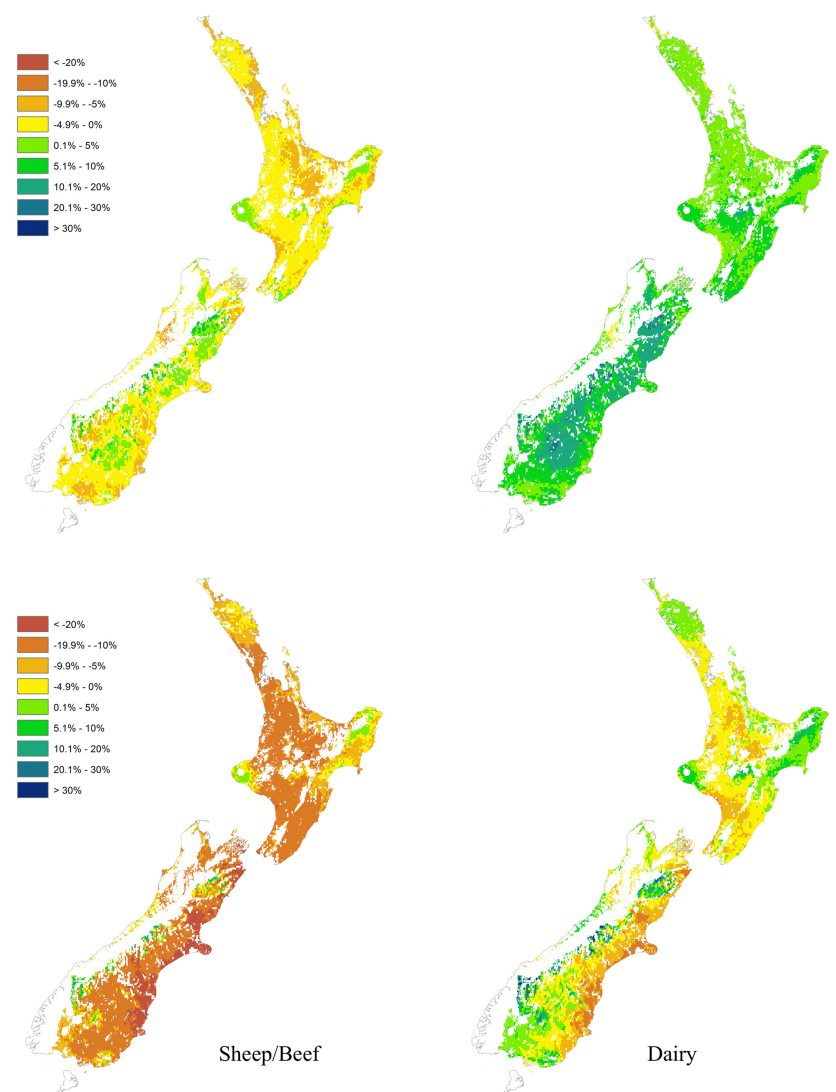

Figure 9. Climate change 2100 MPI (top) and CCC (bottom) model scenarios, average annual total pasture production, percentage change from baseline for sheep/beef (left) and dairy (right). Each map shows national pasture production as if all of the available land (excluding urban and conservation land) were devoted to sheep/beef or dairy agriculture systems and is not an actual representation of current or projected land use.

nitrogen status of dairy systems leads to an increase in photosynthetic water use efficiency.

Seasonal patterns of growth also play an important role. In our climate change scenarios, winter production tends to increase while summer production decreases, as one would expect from an overall average temperature increase. Spring and autumn production trends vary regionally, with no consistent national pattern. Spring and summer in particular are crucial growing seasons in our model as well as for pasture production historically. A breakdown of seasonal rainfall (not shown) indicates that dry summers might drastically reduce production even if the remaining seasons have normal levels of precipitation.

An examination of model results with and without the wind correction factor applied to VPD input indicates that the modified VPD reduces overall national production by 3 $4 \%$ (not shown), although the exact amount varies by region. Hence the general effect of including wind in our simulations is to decrease plant productivity, as is expected from the 


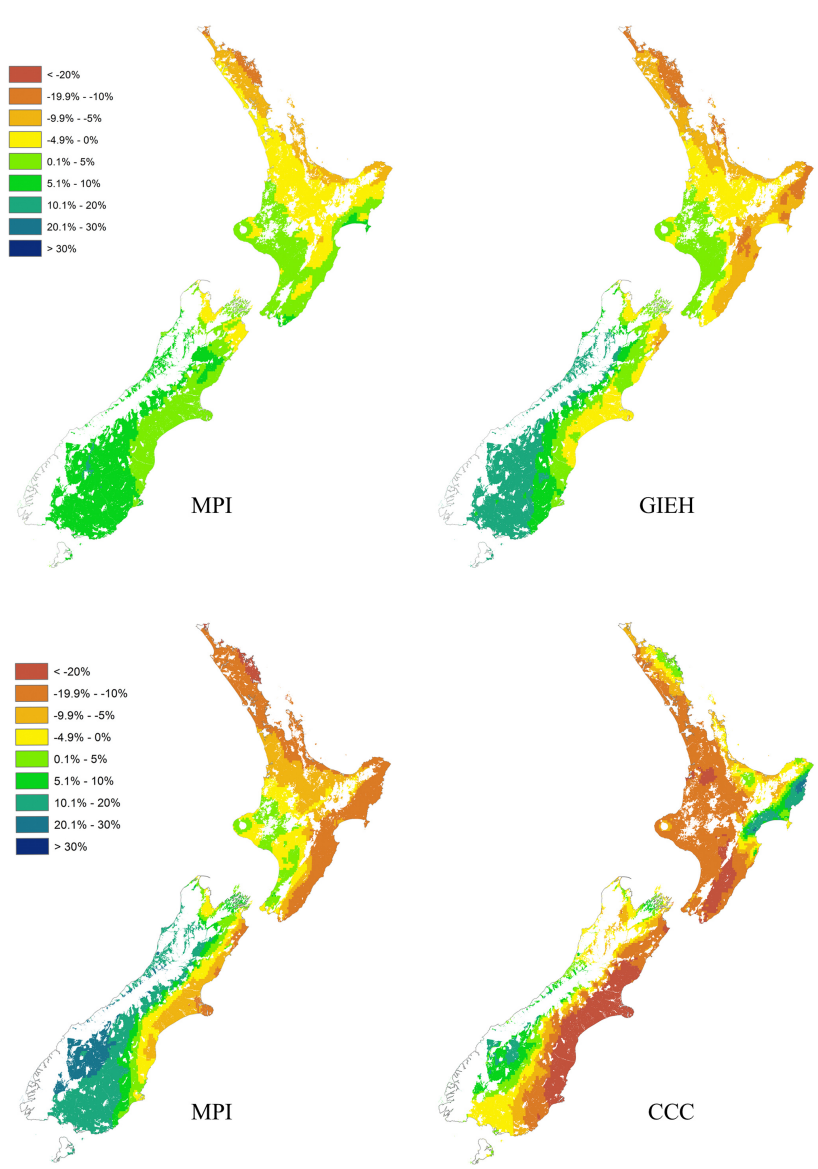

Figure 10. Total annual change in precipitation in 2050 (top) and 2100 (bottom), percentage change from baseline, for MPI (left) and GIEH/CCC (right) climate change scenarios.

elevated water loss that wind induces. Although our climate change scenarios did not modify wind speed from presentday values, global climate models predict that the mean westerly winds over New Zealand will increase, especially over the South Island in winter and spring. If local wind strength does indeed increase in the future, it could cause pasture production to decrease more than we have estimated with our scenarios.

While the model appears most sensitive to weather inputs in the scenarios we considered, parameters involved in grazing and land management are also notable. $\mathrm{CO}_{2}$ fertilisation is, on the whole, a small effect, resulting in only a $0.5 \%$ in production from a $10 \%$ increase in $\mathrm{CO}_{2}$ atmospheric concentrations. Nevertheless, with concentrations projected to increase by $90 \%$ or more by 2100 , it will become much more significant when compared to present day. The model does respond strongly to increases in the plant mortality and nitrogen fixation parameters, having a relatively large positive effect on production in our intensification scenario. Increasing pasture utilisation by 9 and $6 \%$ and nitrogen fixation (or fertiliser application) by 16 and $19 \%$ for sheep/beef and dairy systems, respectively, produce modelled increases in production of 9.5 and $12.5 \%$. This should be interpreted with caution, however; our model is a fairly simplistic representation of intensification, as we have treated all land within each subtype as having equal utilisation and equal potential for production gains. In practice, gains would likely be limited due to resource availability, environmental concerns and the considerable spatial variation in land quality. In addition, we have not explicitly considered changes in carboncycle feedbacks and other biophysical effects due to land-use change and intensification. Other studies have demonstrated that land-use change affects characteristics such as albedo and radiative forcing (Kirschbaum et al., 2011), carbon storage (Bala et al., 2007), and water yield (Beets and Oliver, 2007). The simulation of these effects is beyond the scope of this study but could be considered in future work.

An advantage of the DLUCS methodology is the ability to rapidly sample results from different models and model updates, assuming that strongly interrelated global change issues such as $\mathrm{N}$ status and enhanced $p \mathrm{CO}_{2}$ can be handled within model projections. With the recent release of the IPCC Fifth Assessment Report (AR5), updated climate projections can be incorporated in our simulations through dynamically downscaled weather input to the Biome-BGC model to more fully explore the trends that we discuss here. The possibility of including downscaled changes in wind strength now exists as well, which is currently lacking in our climate change simulations. Output from other biogeochemistry models (including those coupled to GCMs) and improved versions or alternatives replacing Biome-BGC output can be incorporated in a similar way, as well as new developments in LURNZ that add spatial detail and allow for variations in land productivity and carrying capacity (Timar and Kerr, 2014).

\section{Conclusions}

Examining all scenarios modelled here, our results suggest a slight increase in pasture production by 2020 is likely, and increases of $10-15 \%$ are plausible. The outlook for 2050 is also favourable given the scenarios considered. The projected continued conversion of land to high-intensity dairy farming will likely increase total national production. Although climate change could have an adverse effect on particular regions by 2050, our modelling estimates a small overall national increase. $\mathrm{CO}_{2}$ fertilisation effects could also contribute to a slight increase. Projected pasture production in 2100 shows a much larger range of possible outcomes. We find significant differences in the impact on pasture production using weather input from two different GCMs. The CCC model results in a pronounced decline in both sheep/beef and dairy pasture production, while the MPI model shows only a slight decrease in sheep/beef and an increase in dairy production. This highlights that the severity of warming will 
determine the degree of impact on pasture production for both sheep/beef and dairy agriculture in New Zealand.

Our results demonstrate the capability of the Biome-BGC model to provide useful production data when integrated with global change scenarios, including results from the LURNZ model's estimates of land-use change. With downscaled weather input from GCMs, the model infrastructure enables the investigation of regional effects of projected climate change. The Biome-BGC model also offers the potential to model forest ecosystems (with the model's built-in forest modules) and compare productivity across forest and pasture land uses in future studies of global change. The advantage of our approach is the flexibility of the model components and the variety of future change scenarios that we are able to explore with relative ease: by modelling national production for all locations coupled with climate projections or other initial input, we can quickly re-sample the national grid for any modelled land-use change or economic scenario.

Further work to calibrate the Biome-BGC model to New Zealand conditions is needed to refine and confirm results. Iterative improvements in modelling and experimental approaches will be required to provide robust results given the strong interactions and feedbacks in productive ecosystems. One area to investigate is the interaction between climate change and elevated $\mathrm{CO}_{2}$ and water and nitrogen availability, and the differences between time-dependent and quasisteady-state model results. These effects can be constrained by data (for example, eddy covariance towers and FACE experiments) using our modelling approach and have substantial implications for the seasonal cycle of pasture supply, responses to drought and our ability to correctly characterise relative impacts of climate on sheep/beef versus dairy systems. This includes correct estimation of the benefits and limitations of irrigation in both sheep/beef and dairy pasture. Additionally, the simulation of extreme events (e.g. droughts and floods) and new scenarios from the IPCC AR5 with the Biome-BGC model will add to our understanding of the impacts of future climate change. There is also potential for integration with other earth system models. For example, integration with hydrology models would allow us to examine the effects of climate and land-use change on water supply in New Zealand (see, for example, Gerten et al., 2008, and Rockström et al., 2009). While achieving a fully integrated assessment model remains challenging, the DLUCS linkage of models presented here provides a useful methodology to investigate global change, with the ability to generate realistic scenario results on timescales required for policy formulation. 


\section{Appendix A: Biome-BGC parameters}

Eco-physiological parameters used in the Biome-BGC model for dairy and sheep/beef ecosystems. The parameters that were adjusted are marked with a footnote. All other parameters were set to $\mathrm{C} 3$ grass default values provided with the Biome-BGC v4.2 Final Release. Full descriptions of the parameters are contained in the model documentation.

Table A1. Biome-BGC model parameters.

\begin{tabular}{|c|c|c|c|c|}
\hline Parameter description & Sheep/beef baseline & Dairy baseline & $\mathrm{C} 3$ grass default & Type \\
\hline annual whole-plant mortality fraction ${ }^{\mathrm{a}, \mathrm{b}}$ & 0.226 & 0.722 & 0.1 & $\left(1 \mathrm{yr}^{-1}\right)$ \\
\hline annual fire mortality fraction ${ }^{\mathrm{b}}$ & 0.1 & 0.2 & 0.1 & $\left(1 \mathrm{yr}^{-1}\right)$ \\
\hline (ALLOCATION) new fine root $\mathrm{C}$ : new leaf $\mathrm{C}^{\mathrm{b}}$ & 1.43 & 0.246 & 1 & (ratio) \\
\hline (ALLOCATION) current growth proportion ${ }^{\mathrm{b}}$ & 0.84 & 0.424 & 0.5 & (prop.) \\
\hline $\mathrm{C}: \mathrm{N}$ of leaves ${ }^{\mathrm{b}}$ & 24.0 & 24.1 & 24.0 & $\left(\mathrm{kgC} \mathrm{kgN}^{-1}\right)$ \\
\hline $\mathrm{C}: \mathrm{N}$ of leaf litter, after retranslocation ${ }^{\mathrm{b}}$ & 49.0 & 49.0 & 49.0 & $\left(\mathrm{kgC} \mathrm{kgN}^{-1}\right)$ \\
\hline $\mathrm{C}: \mathrm{N}$ of fine roots ${ }^{\mathrm{b}}$ & 42.0 & 42.9 & 42.0 & $\left(\mathrm{kgC} \mathrm{kgN}^{-1}\right)$ \\
\hline canopy average specific leaf area (projected area basis) ${ }^{b}$ & 45.0 & 45.0 & 45.0 & $\left(\mathrm{~m}^{2} \mathrm{kgC}^{-1}\right)$ \\
\hline fraction of leaf $\mathrm{N}$ in Rubisco ${ }^{\mathrm{b}}$ & 0.19 & 0.05 & 0.15 & $(\mathrm{DIM})$ \\
\hline maximum stomatal conductance (projected area basis) ${ }^{\mathrm{b}}$ & 0.00534 & 0.00375 & 0.005 & $\left(\mathrm{~m} \mathrm{~s}^{-1}\right)$ \\
\hline boundary layer conductance (projected area basis) ${ }^{\mathrm{b}}$ & 0.07 & 0.0202 & 0.04 & $\left(\mathrm{~m} \mathrm{~s}^{-1}\right)$ \\
\hline $1=$ WOODY $\quad 0=$ NON-WOODY & 0 & 0 & 0 & (flag) \\
\hline $1=$ EVERGREEN $\quad 0=$ DECIDUOUS & 0 & 0 & 0 & (flag) \\
\hline $1=\mathrm{C} 3 \mathrm{PSN} \quad 0=\mathrm{C} 4 \mathrm{PSN}$ & 1 & 1 & 1 & (flag) \\
\hline $1=$ MODEL PHENOLOGY $\quad 0=$ USER-SPECIFIED PHENOLOGY & 0 & 0 & 0 & (flag) \\
\hline year day to start new growth (phenology flag $=0$ ) & 0 & 0 & 0 & (yday) \\
\hline year day to end litterfall (phenology flag $=0$ ) & 364 & 364 & 364 & (yday) \\
\hline transfer growth period as fraction of growing & 1 & 1 & 1 & (prop.) \\
\hline litterfall as fraction of growing season & 1 & 1 & 1 & (prop.) \\
\hline annual leaf and fine root turnover fraction & 1 & 1 & 1 & $\left(1 \mathrm{yr}^{-1}\right)$ \\
\hline annual live wood turnover fraction & 0 & 0 & 0 & $\left(1 \mathrm{yr}^{-1}\right)$ \\
\hline (ALLOCATION) new stem C: new leaf C & 0 & 0 & 0 & (ratio) \\
\hline (ALLOCATION) new live wood C: new total wood C & 0 & 0 & 0 & (ratio) \\
\hline (ALLOCATION) new coarse root $\mathrm{C}$ : new stem $\mathrm{C}$ & 0 & 0 & 0 & (ratio) \\
\hline $\mathrm{C}: \mathrm{N}$ of live wood & 0 & 0 & 0 & $\left(\mathrm{kgC} \mathrm{kgN}^{-1}\right)$ \\
\hline $\mathrm{C}: \mathrm{N}$ of dead wood & 0 & 0 & 0 & $\left(\mathrm{kgC} \mathrm{kgN}^{-1}\right)$ \\
\hline leaf litter labile proportion & 0.39 & 0.39 & 0.39 & $(\mathrm{DIM})$ \\
\hline leaf litter cellulose proportion & 0.44 & 0.44 & 0.44 & (DIM) \\
\hline leaf litter lignin proportion & 0.17 & 0.17 & 0.17 & (DIM) \\
\hline fine root labile proportion & 0.30 & 0.30 & 0.30 & (DIM) \\
\hline fine root cellulose proportion & 0.45 & 0.45 & 0.45 & (DIM) \\
\hline fine root lignin proportion & 0.25 & 0.25 & 0.25 & (DIM) \\
\hline dead wood cellulose proportion & 0.75 & 0.75 & 0.75 & (DIM) \\
\hline dead wood lignin proportion & 0.25 & 0.25 & 0.25 & (DIM) \\
\hline canopy water interception coefficient & 0.021 & 0.021 & 0.021 & $\left(1 \mathrm{LAI}^{-1} \mathrm{~d}^{-1}\right)$ \\
\hline canopy light extinction coefficient & 0.6 & 0.6 & 0.6 & (DIM) \\
\hline all-sided to projected leaf area ratio & 2.0 & 2.0 & 2.0 & (DIM) \\
\hline ratio of shaded SLA : sunlit SLA & 2.0 & 2.0 & 2.0 & (DIM) \\
\hline cuticular conductance (projected area basis) & 0.00001 & 0.00001 & 0.00001 & $\left(\mathrm{~m} \mathrm{~s}^{-1}\right)$ \\
\hline leaf water potential: start of conductance reduction & -0.6 & -0.6 & -0.6 & $(\mathrm{MPa})$ \\
\hline leaf water potential: complete conductance reduction & -2.3 & -2.3 & -2.3 & $(\mathrm{MPa})$ \\
\hline vapour pressure deficit: start of conductance reduction & 930 & 930 & 930 & $(\mathrm{~Pa})$ \\
\hline vapour pressure deficit: complete conductance reduction & 4100 & 4100 & 4100 & (Pa) \\
\hline
\end{tabular}

${ }^{\text {a }}$ Whole-plant mortality was calculated as (utilisation) $\cdot$ (above-ground growth) / (above-ground + below-ground growth). The ratio below-ground / above-ground is given by the parameter new fine root $\mathrm{C}$ : new leaf $\mathrm{C}{ }^{\mathrm{b}}$ Parameters adjusted during calibration. 
Appendix B: Pasture production results by region and season

The following tables show pasture production results organised by New Zealand's 16 regions and by season, in terms of metabolisable energy (the estimated amount of energy that is available to grazing animals from pasture).

Table B1. Baseline average production by region and season over the period 2001-2009 in units of metabolisable energy.

\begin{tabular}{|c|c|c|c|c|c|c|c|}
\hline \multirow[b]{2}{*}{ Region } & \multirow{2}{*}{$\begin{array}{l}\text { Area } \\
\text { (kha) }\end{array}$} & Winter & Spring & Summer & Autumn & \multirow[b]{2}{*}{ Average } & \multirow[b]{2}{*}{ Total ME (TJ) } \\
\hline & & \multicolumn{4}{|c|}{ Average production $\left(\mathrm{MJ} \mathrm{ha}^{-1} \mathrm{~d}^{-1}\right)$} & & \\
\hline \multicolumn{8}{|l|}{ Sheep \& beef } \\
\hline Northland & 239 & 138 & 423 & 296 & 199 & 264 & 22963 \\
\hline Auckland & 85 & 129 & 445 & 304 & 168 & 262 & 8158 \\
\hline Waikato & 473 & 112 & 421 & 368 & 201 & 276 & 47532 \\
\hline Bay of Plenty & 66 & 108 & 402 & 366 & 219 & 274 & 6580 \\
\hline Gisborne & 327 & 106 & 431 & 321 & 200 & 264 & 31582 \\
\hline Manawatu-Wanganui & 936 & 92 & 415 & 373 & 185 & 266 & 90856 \\
\hline Hawkes Bay & 586 & 94 & 398 & 212 & 179 & 220 & 47121 \\
\hline Taranaki & 125 & 105 & 398 & 412 & 214 & 282 & 12850 \\
\hline Tasman & 57 & 86 & 406 & 268 & 171 & 233 & 4841 \\
\hline Marlborough & 310 & 59 & 310 & 230 & 133 & 183 & 20703 \\
\hline Westland & 32 & 81 & 355 & 378 & 204 & 255 & 2949 \\
\hline Wellington & 281 & 95 & 440 & 249 & 156 & 235 & 24064 \\
\hline Nelson City & 2 & 87 & 417 & 274 & 142 & 230 & 208 \\
\hline Canterbury & 1824 & 54 & 307 & 211 & 131 & 176 & 117080 \\
\hline Otago & 1738 & 46 & 296 & 248 & 134 & 181 & 114986 \\
\hline Southland & 698 & 62 & 376 & 370 & 176 & 246 & 62653 \\
\hline National & 7778 & 73 & 356 & 279 & 159 & 217 & 615126 \\
\hline \multicolumn{8}{|l|}{ Dairy } \\
\hline Northland & 172 & 221 & 617 & 464 & 376 & 420 & 26334 \\
\hline Auckland & 53 & 209 & 629 & 504 & 342 & 421 & 8104 \\
\hline Waikato & 487 & 184 & 628 & 510 & 364 & 422 & 74904 \\
\hline Bay of Plenty & 80 & 181 & 613 & 540 & 400 & 434 & 12611 \\
\hline Gisborne & 3 & 176 & 580 & 536 & 392 & 421 & 384 \\
\hline Manawatu-Wanganui & 127 & 149 & 602 & 538 & 314 & 401 & 18595 \\
\hline Hawkes Bay & 16 & 136 & 581 & 454 & 334 & 376 & 2159 \\
\hline Taranaki & 215 & 168 & 594 & 615 & 394 & 443 & 34784 \\
\hline Tasman & 27 & 139 & 582 & 548 & 357 & 406 & 4043 \\
\hline Marlborough & 9 & 126 & 549 & 456 & 303 & 358 & 1210 \\
\hline Westland & 52 & 124 & 532 & 582 & 373 & 402 & 7690 \\
\hline Wellington & 30 & 142 & 612 & 433 & 298 & 371 & 4016 \\
\hline Nelson City & 0 & 121 & 517 & 339 & 295 & 318 & 49 \\
\hline Canterbury & 119 & 103 & 513 & 362 & 281 & 315 & 13723 \\
\hline Otago & 62 & 88 & 523 & 488 & 287 & 346 & 7799 \\
\hline Southland & 106 & 93 & 529 & 564 & 332 & 379 & 14609 \\
\hline National & 1557 & 163 & 594 & 515 & 353 & 406 & 231014 \\
\hline Combined national & 9335 & & & & & & 846140 \\
\hline
\end{tabular}


Table B2. Baseline average production by region and season over the period 1997-2011 in units of metabolisable energy.

\begin{tabular}{|c|c|c|c|c|c|c|c|}
\hline \multirow[b]{2}{*}{ Region } & \multirow{2}{*}{$\begin{array}{l}\text { Area } \\
\text { (kha) }\end{array}$} & Winter & Spring & Summer & Autumn & \multirow[b]{2}{*}{ Average } & \multirow[b]{2}{*}{ Total ME (TJ) } \\
\hline & & \multicolumn{4}{|c|}{ Average production $\left(\mathrm{MJ} \mathrm{ha}^{-1} \mathrm{~d}^{-1}\right)$} & & \\
\hline \multicolumn{8}{|l|}{ Sheep \& beef } \\
\hline Northland & 239 & 131 & 435 & 247 & 151 & 241 & 20999 \\
\hline Auckland & 85 & 123 & 452 & 266 & 134 & 244 & 7601 \\
\hline Waikato & 473 & 105 & 446 & 298 & 143 & 248 & 42743 \\
\hline Bay of Plenty & 66 & 102 & 416 & 298 & 174 & 248 & 5951 \\
\hline Gisborne & 327 & 103 & 422 & 341 & 196 & 266 & 31745 \\
\hline Manawatu-Wanganui & 936 & 87 & 438 & 288 & 137 & 237 & 81024 \\
\hline Hawkes Bay & 586 & 88 & 387 & 188 & 153 & 204 & 43661 \\
\hline Taranaki & 125 & 101 & 421 & 402 & 177 & 275 & 12535 \\
\hline Tasman & 57 & 83 & 403 & 231 & 152 & 217 & 4524 \\
\hline Marlborough & 310 & 58 & 305 & 253 & 134 & 187 & 21235 \\
\hline Westland & 32 & 79 & 369 & 308 & 170 & 231 & 2677 \\
\hline Wellington & 281 & 89 & 437 & 216 & 129 & 218 & 22317 \\
\hline Nelson City & 2 & 83 & 408 & 258 & 117 & 217 & 196 \\
\hline Canterbury & 1824 & 51 & 291 & 176 & 122 & 160 & 106386 \\
\hline Otago & 1738 & 43 & 272 & 194 & 119 & 157 & 99507 \\
\hline Southland & 698 & 57 & 369 & 268 & 146 & 210 & 53466 \\
\hline National & 7778 & 69 & 350 & 230 & 135 & 196 & 556567 \\
\hline \multicolumn{8}{|l|}{ Dairy } \\
\hline Northland & 172 & 213 & 617 & 426 & 325 & 395 & 24815 \\
\hline Auckland & 53 & 199 & 637 & 477 & 293 & 402 & 7733 \\
\hline Waikato & 487 & 170 & 627 & 470 & 308 & 394 & 69953 \\
\hline Bay of Plenty & 80 & 169 & 607 & 468 & 354 & 399 & 11617 \\
\hline Gisborne & 3 & 173 & 577 & 539 & 380 & 418 & 381 \\
\hline Manawatu-Wanganui & 127 & 137 & 604 & 470 & 261 & 368 & 17063 \\
\hline Hawkes Bay & 16 & 126 & 561 & 409 & 303 & 350 & 2007 \\
\hline Taranaki & 215 & 168 & 598 & 620 & 393 & 445 & 34946 \\
\hline Tasman & 27 & 133 & 578 & 510 & 325 & 386 & 3843 \\
\hline Marlborough & 9 & 118 & 529 & 422 & 276 & 337 & 1136 \\
\hline Westland & 52 & 123 & 537 & 547 & 348 & 389 & 7434 \\
\hline Wellington & 30 & 131 & 599 & 369 & 264 & 341 & 3690 \\
\hline Nelson City & 0.4 & 114 & 497 & 333 & 266 & 302 & 47 \\
\hline Canterbury & 119 & 89 & 462 & 289 & 246 & 272 & 11835 \\
\hline Otago & 62 & 78 & 485 & 399 & 251 & 304 & 6833 \\
\hline Southland & 106 & 85 & 525 & 497 & 282 & 347 & 13384 \\
\hline National & 1557 & 153 & 588 & 472 & 311 & 381 & 216717 \\
\hline Combined national & 9335 & & & & & & 773284 \\
\hline
\end{tabular}


Table B3. Elevated $\mathrm{CO}_{2} 2020$.

\begin{tabular}{|c|c|c|c|c|c|c|c|c|}
\hline \multirow[b]{2}{*}{ Region } & \multirow{2}{*}{$\begin{array}{l}\text { Area } \\
\text { (kha) }\end{array}$} & Winter & Spring & Summer & Autumn & \multirow[b]{2}{*}{ Average } & \multirow{2}{*}{$\begin{array}{r}\text { Total ME } \\
(\mathrm{TJ})\end{array}$} & \multirow{2}{*}{$\begin{array}{r}\text { Change } \\
(\%)\end{array}$} \\
\hline & & \multicolumn{4}{|c|}{ Average production $\left(\mathrm{MJ} \mathrm{ha}^{-1} \mathrm{~d}^{-1}\right)$} & & & \\
\hline \multicolumn{9}{|l|}{ Sheep \& beef } \\
\hline Northland & 239 & 140 & 423 & 297 & 199 & 265 & 23035 & $0.3 \%$ \\
\hline Auckland & 85 & 131 & 445 & 305 & 169 & 263 & 8188 & $0.4 \%$ \\
\hline Waikato & 473 & 113 & 421 & 369 & 201 & 276 & 47622 & $0.2 \%$ \\
\hline Bay of Plenty & 66 & 108 & 402 & 367 & 219 & 274 & 6590 & $0.2 \%$ \\
\hline Gisborne & 327 & 107 & 431 & 323 & 200 & 265 & 31680 & $0.3 \%$ \\
\hline Manawatu-Wanganui & 936 & 92 & 415 & 374 & 185 & 267 & 91042 & $0.2 \%$ \\
\hline Hawkes Bay & 586 & 95 & 398 & 213 & 180 & 222 & 47378 & $0.5 \%$ \\
\hline Taranaki & 125 & 105 & 397 & 412 & 214 & 282 & 12859 & $0.1 \%$ \\
\hline Tasman & 57 & 87 & 407 & 269 & 172 & 234 & 4861 & $0.4 \%$ \\
\hline Marlborough & 310 & 59 & 310 & 231 & 134 & 184 & 20807 & $0.5 \%$ \\
\hline Westland & 32 & 82 & 355 & 379 & 205 & 255 & 2955 & $0.2 \%$ \\
\hline Wellington & 281 & 96 & 441 & 250 & 157 & 236 & 24186 & $0.5 \%$ \\
\hline Nelson City & 2 & 88 & 418 & 275 & 144 & 231 & 209 & $0.5 \%$ \\
\hline Canterbury & 1824 & 55 & 308 & 213 & 133 & 177 & 117777 & $0.6 \%$ \\
\hline Otago & 1738 & 47 & 297 & 249 & 135 & 182 & 115538 & $0.5 \%$ \\
\hline Southland & 698 & 63 & 376 & 371 & 176 & 247 & 62803 & $0.2 \%$ \\
\hline National & 7778 & 74 & 356 & 280 & 160 & 218 & 617531 & $0.4 \%$ \\
\hline \multicolumn{9}{|l|}{ Dairy } \\
\hline Northland & 172 & 225 & 620 & 466 & 377 & 422 & 26467 & $0.5 \%$ \\
\hline Auckland & 53 & 213 & 632 & 505 & 342 & 423 & 8143 & $0.5 \%$ \\
\hline Waikato & 487 & 187 & 631 & 512 & 364 & 424 & 75290 & $0.5 \%$ \\
\hline Bay of Plenty & 80 & 183 & 616 & 542 & 400 & 435 & 12664 & $0.4 \%$ \\
\hline Gisborne & 3 & 178 & 583 & 537 & 392 & 423 & 386 & $0.4 \%$ \\
\hline Manawatu-Wanganui & 127 & 151 & 607 & 539 & 314 & 403 & 18695 & $0.5 \%$ \\
\hline Hawkes Bay & 16 & 138 & 585 & 456 & 335 & 378 & 2172 & $0.6 \%$ \\
\hline Taranaki & 215 & 171 & 597 & 615 & 394 & 444 & 34915 & $0.4 \%$ \\
\hline Tasman & 27 & 141 & 585 & 550 & 357 & 408 & 4061 & $0.4 \%$ \\
\hline Marlborough & 9 & 128 & 553 & 458 & 304 & 361 & 1218 & $0.6 \%$ \\
\hline Westland & 52 & 126 & 535 & 583 & 373 & 404 & 7724 & $0.4 \%$ \\
\hline Wellington & 30 & 145 & 617 & 435 & 299 & 374 & 4046 & $0.8 \%$ \\
\hline Nelson City & 0 & 123 & 522 & 342 & 296 & 321 & 50 & $0.8 \%$ \\
\hline Canterbury & 119 & 105 & 519 & 365 & 283 & 318 & 13851 & $0.9 \%$ \\
\hline Otago & 62 & 90 & 527 & 489 & 288 & 349 & 7846 & $0.6 \%$ \\
\hline Southland & 106 & 94 & 533 & 564 & 332 & 381 & 14675 & $0.5 \%$ \\
\hline National & 1557 & 166 & 598 & 517 & 354 & 409 & 232203 & $0.5 \%$ \\
\hline Combined national & 9335 & & & & & & 849734 & $0.4 \%$ \\
\hline
\end{tabular}


Table B4. Intensification 2020.

\begin{tabular}{|c|c|c|c|c|c|c|c|c|}
\hline \multirow[b]{2}{*}{ Region } & \multirow{2}{*}{$\begin{array}{l}\text { Area } \\
\text { (kha) }\end{array}$} & Winter & Spring & Summer & Autumn & \multirow[b]{2}{*}{ Average } & \multirow{2}{*}{$\begin{array}{r}\text { Total ME } \\
(\mathrm{TJ})\end{array}$} & \multirow{2}{*}{$\begin{array}{r}\text { Change } \\
(\%)\end{array}$} \\
\hline & & \multicolumn{4}{|c|}{ Average production $\left(\mathrm{MJ} \mathrm{ha}^{-1} \mathrm{~d}^{-1}\right)$} & & & \\
\hline \multicolumn{9}{|l|}{ Sheep \& beef } \\
\hline Northland & 239 & 153 & 476 & 318 & 217 & 291 & 25337 & $10.3 \%$ \\
\hline Auckland & 85 & 142 & 499 & 320 & 178 & 285 & 8878 & $8.8 \%$ \\
\hline Waikato & 473 & 126 & 482 & 406 & 217 & 308 & 53058 & $11.6 \%$ \\
\hline Bay of Plenty & 66 & 122 & 461 & 405 & 240 & 307 & 7381 & $12.2 \%$ \\
\hline Gisborne & 327 & 117 & 485 & 348 & 218 & 292 & 34886 & $10.5 \%$ \\
\hline Manawatu-Wanganui & 936 & 102 & 474 & 411 & 199 & 297 & 101291 & $11.5 \%$ \\
\hline Hawkes Bay & 586 & 103 & 438 & 223 & 194 & 240 & 51212 & $8.7 \%$ \\
\hline Taranaki & 125 & 119 & 462 & 471 & 235 & 322 & 14652 & $14.0 \%$ \\
\hline Tasman & 57 & 94 & 451 & 287 & 185 & 254 & 5286 & $9.2 \%$ \\
\hline Marlborough & 310 & 64 & 341 & 247 & 143 & 199 & 22533 & $8.8 \%$ \\
\hline Westland & 32 & 90 & 401 & 418 & 223 & 283 & 3279 & $11.2 \%$ \\
\hline Wellington & 281 & 104 & 488 & 261 & 169 & 255 & 26180 & $8.8 \%$ \\
\hline Nelson City & 2 & 96 & 462 & 290 & 149 & 250 & 225 & $8.4 \%$ \\
\hline Canterbury & 1824 & 59 & 334 & 224 & 141 & 190 & 126240 & $7.8 \%$ \\
\hline Otago & 1738 & 51 & 325 & 265 & 144 & 196 & 124421 & $8.2 \%$ \\
\hline Southland & 698 & 68 & 423 & 404 & 189 & 271 & 69003 & $10.1 \%$ \\
\hline National & 7778 & 80 & 396 & 301 & 172 & 237 & 673861 & $9.5 \%$ \\
\hline \multicolumn{9}{|l|}{ Dairy } \\
\hline Northland & 172 & 246 & 698 & 520 & 428 & 473 & 29678 & $12.7 \%$ \\
\hline Auckland & 53 & 233 & 712 & 565 & 387 & 474 & 9136 & $12.7 \%$ \\
\hline Waikato & 487 & 204 & 708 & 574 & 411 & 474 & 84222 & $12.4 \%$ \\
\hline Bay of Plenty & 80 & 202 & 694 & 610 & 457 & 491 & 14268 & $13.1 \%$ \\
\hline Gisborne & 3 & 197 & 659 & 612 & 449 & 479 & 437 & $13.9 \%$ \\
\hline Manawatu-Wanganui & 127 & 164 & 675 & 605 & 353 & 449 & 20850 & $12.1 \%$ \\
\hline Hawkes Bay & 16 & 149 & 649 & 505 & 377 & 420 & 2412 & $11.7 \%$ \\
\hline Taranaki & 215 & 189 & 673 & 708 & 451 & 505 & 39681 & $14.1 \%$ \\
\hline Tasman & 27 & 154 & 654 & 621 & 406 & 459 & 4565 & $12.9 \%$ \\
\hline Marlborough & 9 & 139 & 614 & 515 & 340 & 402 & 1357 & $12.2 \%$ \\
\hline Westland & 52 & 136 & 595 & 662 & 423 & 454 & 8675 & $12.8 \%$ \\
\hline Wellington & 30 & 155 & 680 & 478 & 335 & 412 & 4461 & $11.1 \%$ \\
\hline Nelson City & 0 & 131 & 571 & 375 & 327 & 351 & 54 & $10.4 \%$ \\
\hline Canterbury & 119 & 112 & 563 & 400 & 312 & 347 & 15117 & $10.2 \%$ \\
\hline Otago & 62 & 96 & 578 & 543 & 319 & 384 & 8647 & $10.9 \%$ \\
\hline Southland & 106 & 101 & 590 & 639 & 369 & 425 & 16355 & $12.0 \%$ \\
\hline National & 1557 & 181 & 668 & 581 & 399 & 457 & 259915 & $12.5 \%$ \\
\hline Combined national & 9335 & & & & & & 933776 & $10.4 \%$ \\
\hline
\end{tabular}


Table B5. Climate change 2050 (GIEH model).

\begin{tabular}{|c|c|c|c|c|c|c|c|c|}
\hline \multirow[b]{2}{*}{ Region } & \multirow{2}{*}{$\begin{array}{l}\text { Area } \\
\text { (kha) }\end{array}$} & Winter & Spring & Summer & Autumn & \multirow[b]{2}{*}{ Average } & \multirow{2}{*}{$\begin{array}{r}\text { Total ME } \\
(\mathrm{TJ})\end{array}$} & \multirow{2}{*}{$\begin{array}{r}\text { Chang } \\
(\%\end{array}$} \\
\hline & & \multicolumn{4}{|c|}{ Average production $\left(\mathrm{MJ} \mathrm{ha}^{-1} \mathrm{~d}^{-1}\right)$} & & & \\
\hline \multicolumn{9}{|l|}{ Sheep \& beef } \\
\hline Northland & 239 & 148 & 421 & 288 & 204 & 265 & 23103 & $0.6 \%$ \\
\hline Auckland & 85 & 140 & 442 & 299 & 178 & 265 & 8262 & $1.3 \%$ \\
\hline Waikato & 473 & 120 & 421 & 369 & 205 & 279 & 48129 & $1.3 \%$ \\
\hline Bay of Plenty & 66 & 115 & 405 & 361 & 222 & 276 & 6637 & $0.9 \%$ \\
\hline Gisborne & 327 & 116 & 426 & 305 & 221 & 267 & 31885 & $1.0 \%$ \\
\hline Manawatu-Wanganui & 936 & 98 & 417 & 372 & 191 & 269 & 91999 & $1.3 \%$ \\
\hline Hawkes Bay & 586 & 104 & 392 & 201 & 207 & 226 & 48335 & $2.6 \%$ \\
\hline Taranaki & 125 & 111 & 399 & 412 & 214 & 284 & 12943 & $0.7 \%$ \\
\hline Tasman & 57 & 94 & 413 & 266 & 175 & 237 & 4929 & $1.8 \%$ \\
\hline Marlborough & 310 & 65 & 315 & 218 & 138 & 184 & 20860 & $0.8 \%$ \\
\hline Westland & 32 & 87 & 358 & 377 & 203 & 256 & 2967 & $0.6 \%$ \\
\hline Wellington & 281 & 103 & 442 & 239 & 174 & 239 & 24545 & $2.0 \%$ \\
\hline Nelson City & 2 & 94 & 423 & 261 & 149 & 232 & 209 & $0.7 \%$ \\
\hline Canterbury & 1824 & 61 & 311 & 209 & 142 & 181 & 120235 & $2.7 \%$ \\
\hline Otago & 1738 & 52 & 307 & 250 & 139 & 187 & 118549 & $3.1 \%$ \\
\hline Southland & 698 & 67 & 384 & 373 & 177 & 250 & 63704 & $1.7 \%$ \\
\hline National & 7778 & 80 & 360 & 276 & 168 & 221 & 627293 & $2.0 \%$ \\
\hline \multicolumn{9}{|l|}{ Dairy } \\
\hline Northland & 172 & 250 & 630 & 456 & 385 & 430 & 26999 & $2.5 \%$ \\
\hline Auckland & 53 & 237 & 643 & 500 & 351 & 433 & 8332 & $2.8 \%$ \\
\hline Waikato & 487 & 210 & 648 & 517 & 378 & 438 & 77837 & $3.9 \%$ \\
\hline Bay of Plenty & 80 & 205 & 632 & 538 & 412 & 447 & 12995 & $3.0 \%$ \\
\hline Gisborne & 3 & 201 & 596 & 529 & 410 & 434 & 396 & $3.1 \%$ \\
\hline Manawatu-Wanganui & 127 & 169 & 632 & 542 & 321 & 416 & 19309 & $3.8 \%$ \\
\hline Hawkes Bay & 16 & 161 & 604 & 438 & 372 & 393 & 2258 & $4.6 \%$ \\
\hline Taranaki & 215 & 188 & 618 & 618 & 396 & 455 & 35757 & $2.8 \%$ \\
\hline Tasman & 27 & 158 & 609 & 552 & 359 & 419 & 4172 & $3.2 \%$ \\
\hline Marlborough & 9 & 148 & 575 & 449 & 309 & 370 & 1250 & $3.3 \%$ \\
\hline Westland & 52 & 139 & 556 & 584 & 374 & 413 & 7899 & $2.7 \%$ \\
\hline Wellington & 30 & 165 & 642 & 429 & 319 & 389 & 4207 & $4.8 \%$ \\
\hline Nelson City & 0 & 142 & 545 & 334 & 311 & 333 & 52 & $4.7 \%$ \\
\hline Canterbury & 119 & 126 & 539 & 369 & 309 & 336 & 14629 & $6.6 \%$ \\
\hline Otago & 62 & 103 & 555 & 491 & 299 & 362 & 8153 & $4.5 \%$ \\
\hline Southland & 106 & 107 & 563 & 569 & 338 & 394 & 15181 & $3.9 \%$ \\
\hline National & 1557 & 186 & 617 & 518 & 364 & 421 & 239427 & $3.6 \%$ \\
\hline Combined national & 9335 & & & & & & 866720 & $2.4 \%$ \\
\hline
\end{tabular}


Table B6. Climate change 2050 (MPI model).

\begin{tabular}{|c|c|c|c|c|c|c|c|c|}
\hline \multirow[b]{2}{*}{ Region } & \multirow{2}{*}{$\begin{array}{l}\text { Area } \\
\text { (kha) }\end{array}$} & Winter & Spring & Summer & Autumn & \multirow[b]{2}{*}{ Average } & \multirow{2}{*}{$\begin{array}{r}\text { Total ME } \\
(\mathrm{TJ})\end{array}$} & \multirow{2}{*}{$\begin{array}{r}\text { Change } \\
(\%)\end{array}$} \\
\hline & & \multicolumn{4}{|c|}{ Average production $\left(\mathrm{MJ} \mathrm{ha}^{-1} \mathrm{~d}^{-1}\right)$} & & & \\
\hline \multicolumn{9}{|l|}{ Sheep \& beef } \\
\hline Northland & 239 & 154 & 414 & 266 & 210 & 261 & 22729 & $-1.0 \%$ \\
\hline Auckland & 85 & 146 & 441 & 265 & 182 & 259 & 8063 & $-1.2 \%$ \\
\hline Waikato & 473 & 128 & 423 & 355 & 204 & 277 & 47869 & $0.7 \%$ \\
\hline Bay of Plenty & 66 & 124 & 406 & 345 & 225 & 275 & 6611 & $0.5 \%$ \\
\hline Gisborne & 327 & 124 & 422 & 284 & 222 & 263 & 31424 & $-0.5 \%$ \\
\hline Manawatu-Wanganui & 936 & 105 & 420 & 353 & 189 & 267 & 91174 & $0.4 \%$ \\
\hline Hawkes Bay & 586 & 111 & 365 & 189 & 213 & 219 & 46914 & $-0.4 \%$ \\
\hline Taranaki & 125 & 118 & 402 & 408 & 211 & 285 & 12970 & $0.9 \%$ \\
\hline Tasman & 57 & 101 & 407 & 244 & 177 & 232 & 4835 & $-0.1 \%$ \\
\hline Marlborough & 310 & 69 & 305 & 199 & 140 & 178 & 20180 & $-2.5 \%$ \\
\hline Westland & 32 & 91 & 359 & 372 & 201 & 256 & 2962 & $0.4 \%$ \\
\hline Wellington & 281 & 110 & 435 & 208 & 178 & 233 & 23850 & $-0.9 \%$ \\
\hline Nelson City & 2 & 101 & 415 & 228 & 152 & 224 & 202 & $-2.6 \%$ \\
\hline Canterbury & 1824 & 65 & 298 & 196 & 145 & 176 & 117198 & $0.1 \%$ \\
\hline Otago & 1738 & 55 & 305 & 235 & 139 & 184 & 116504 & $1.3 \%$ \\
\hline Southland & 698 & 71 & 389 & 360 & 174 & 249 & 63274 & $1.0 \%$ \\
\hline National & 7778 & 85 & 354 & 260 & 169 & 217 & 616759 & $0.3 \%$ \\
\hline \multicolumn{9}{|l|}{ Dairy } \\
\hline Northland & 172 & 267 & 619 & 424 & 401 & 428 & 26855 & $2.0 \%$ \\
\hline Auckland & 53 & 255 & 645 & 463 & 358 & 430 & 8284 & $2.2 \%$ \\
\hline Waikato & 487 & 232 & 644 & 495 & 385 & 439 & 78004 & $4.1 \%$ \\
\hline Bay of Plenty & 80 & 227 & 630 & 514 & 423 & 449 & 13044 & $3.4 \%$ \\
\hline Gisborne & 3 & 220 & 592 & 512 & 415 & 435 & 397 & $3.3 \%$ \\
\hline Manawatu-Wanganui & 127 & 187 & 639 & 514 & 321 & 415 & 19268 & $3.6 \%$ \\
\hline Hawkes Bay & 16 & 182 & 586 & 409 & 388 & 391 & 2246 & $4.0 \%$ \\
\hline Taranaki & 215 & 205 & 625 & 615 & 397 & 460 & 36167 & $4.0 \%$ \\
\hline Tasman & 27 & 175 & 614 & 533 & 366 & 422 & 4198 & $3.8 \%$ \\
\hline Marlborough & 9 & 167 & 566 & 428 & 317 & 369 & 1247 & $3.0 \%$ \\
\hline Westland & 52 & 151 & 563 & 583 & 378 & 419 & 8003 & $4.1 \%$ \\
\hline Wellington & 30 & 183 & 642 & 389 & 328 & 386 & 4174 & $3.9 \%$ \\
\hline Nelson City & 0 & 163 & 527 & 319 & 324 & 333 & 52 & $4.8 \%$ \\
\hline Canterbury & 119 & 144 & 508 & 350 & 329 & 333 & 14491 & $5.6 \%$ \\
\hline Otago & 62 & 115 & 562 & 468 & 302 & 362 & 8146 & $4.4 \%$ \\
\hline Southland & 106 & 119 & 576 & 562 & 341 & 400 & 15393 & $5.4 \%$ \\
\hline National & 1557 & 204 & 615 & 498 & 372 & 422 & 239967 & $3.9 \%$ \\
\hline Combined national & 9335 & & & & & & 856726 & $1.3 \%$ \\
\hline
\end{tabular}


Table B7. Climate change 2100 (CCC model).

\begin{tabular}{|c|c|c|c|c|c|c|c|c|}
\hline \multirow[b]{2}{*}{ Region } & \multirow{2}{*}{$\begin{array}{l}\text { Area } \\
\text { (kha) }\end{array}$} & Winter & Spring & Summer & Autumn & \multirow[b]{2}{*}{ Average } & \multirow{2}{*}{$\begin{array}{r}\text { Total ME } \\
(\mathrm{TJ})\end{array}$} & \multirow{2}{*}{$\begin{array}{r}\text { Change } \\
(\%)\end{array}$} \\
\hline & & \multicolumn{4}{|c|}{ Average production $\left(\mathrm{MJ} \mathrm{ha}^{-1} \mathrm{~d}^{-1}\right)$} & & & \\
\hline \multicolumn{9}{|l|}{ Sheep \& beef } \\
\hline Northland & 239 & 172 & 390 & 127 & 211 & 225 & 19603 & $-6.6 \%$ \\
\hline Auckland & 85 & 156 & 408 & 88 & 179 & 207 & 6470 & $-14.9 \%$ \\
\hline Waikato & 473 & 152 & 443 & 113 & 158 & 216 & 37346 & $-12.6 \%$ \\
\hline Bay of Plenty & 66 & 151 & 403 & 112 & 213 & 220 & 5289 & $-11.1 \%$ \\
\hline Gisborne & 327 & 157 & 411 & 216 & 235 & 255 & 30427 & $-4.2 \%$ \\
\hline Manawatu-Wanganui & 936 & 134 & 433 & 102 & 147 & 204 & 69621 & $-14.1 \%$ \\
\hline Hawkes Bay & 586 & 138 & 299 & 93 & 221 & 188 & 40090 & $-8.2 \%$ \\
\hline Taranaki & 125 & 144 & 471 & 257 & 133 & 251 & 11439 & $-8.7 \%$ \\
\hline Tasman & 57 & 132 & 390 & 90 & 157 & 192 & 3999 & $-11.6 \%$ \\
\hline Marlborough & 310 & 94 & 310 & 116 & 130 & 162 & 18406 & $-13.3 \%$ \\
\hline Westland & 32 & 107 & 384 & 205 & 135 & 208 & 2404 & $-10.2 \%$ \\
\hline Wellington & 281 & 138 & 388 & 59 & 163 & 187 & 19165 & $-14.1 \%$ \\
\hline Nelson City & 2 & 119 & 384 & 82 & 148 & 183 & 165 & $-15.5 \%$ \\
\hline Canterbury & 1824 & 80 & 243 & 80 & 116 & 130 & 86316 & $-18.9 \%$ \\
\hline Otago & 1738 & 68 & 259 & 109 & 98 & 134 & 84713 & $-14.9 \%$ \\
\hline Southland & 698 & 84 & 375 & 168 & 126 & 188 & 47947 & $-10.3 \%$ \\
\hline National & 7778 & 105 & 326 & 112 & 139 & 170 & 483402 & $-13.1 \%$ \\
\hline \multicolumn{9}{|l|}{ Dairy } \\
\hline Northland & 172 & 327 & 577 & 275 & 419 & 400 & 25077 & $1.1 \%$ \\
\hline Auckland & 53 & 311 & 644 & 249 & 367 & 393 & 7560 & $-2.2 \%$ \\
\hline Waikato & 487 & 289 & 635 & 249 & 347 & 380 & 67506 & $-3.5 \%$ \\
\hline Bay of Plenty & 80 & 294 & 606 & 259 & 427 & 396 & 11524 & $-0.8 \%$ \\
\hline Gisborne & 3 & 294 & 588 & 435 & 437 & 439 & 400 & $5.0 \%$ \\
\hline Manawatu-Wanganui & 127 & 242 & 645 & 238 & 266 & 348 & 16136 & $-5.4 \%$ \\
\hline Hawkes Bay & 16 & 248 & 510 & 249 & 409 & 354 & 2032 & $1.3 \%$ \\
\hline Taranaki & 215 & 268 & 697 & 580 & 318 & 466 & 36594 & $4.7 \%$ \\
\hline Tasman & 27 & 241 & 638 & 346 & 318 & 386 & 3837 & $-0.2 \%$ \\
\hline Marlborough & 9 & 219 & 550 & 228 & 294 & 323 & 1090 & $-4.1 \%$ \\
\hline Westland & 52 & 208 & 617 & 435 & 305 & 391 & 7470 & $0.5 \%$ \\
\hline Wellington & 30 & 244 & 602 & 173 & 302 & 330 & 3574 & $-3.1 \%$ \\
\hline Nelson City & 0 & 211 & 484 & 160 & 321 & 294 & 46 & $-2.7 \%$ \\
\hline Canterbury & 119 & 176 & 387 & 158 & 276 & 249 & 10859 & $-8.2 \%$ \\
\hline Otago & 62 & 146 & 488 & 261 & 239 & 283 & 6381 & $-6.6 \%$ \\
\hline Southland & 106 & 153 & 613 & 380 & 257 & 351 & 13507 & $0.9 \%$ \\
\hline National & 1557 & 258 & 608 & 306 & 331 & 376 & 213593 & $-1.4 \%$ \\
\hline Combined national & 9335 & & & & & & 696995 & $-9.9 \%$ \\
\hline
\end{tabular}


Table B8. Climate change 2100 (MPI model).

\begin{tabular}{|c|c|c|c|c|c|c|c|c|}
\hline \multirow[b]{2}{*}{ Region } & \multirow{2}{*}{$\begin{array}{l}\text { Area } \\
\text { (kha) }\end{array}$} & Winter & Spring & Summer & Autumn & \multirow[b]{2}{*}{ Average } & \multirow{2}{*}{$\begin{array}{r}\text { Total ME } \\
(\mathrm{TJ})\end{array}$} & \multirow{2}{*}{$\begin{array}{r}\text { Change } \\
(\%)\end{array}$} \\
\hline & & \multicolumn{4}{|c|}{ Average production $\left(\mathrm{MJ} \mathrm{ha}^{-1} \mathrm{~d}^{-1}\right)$} & & & \\
\hline \multicolumn{9}{|l|}{ Sheep \& beef } \\
\hline Northland & 239 & 168 & 399 & 183 & 180 & 233 & 20258 & $-3.5 \%$ \\
\hline Auckland & 85 & 153 & 422 & 172 & 157 & 226 & 7047 & $-7.3 \%$ \\
\hline Waikato & 473 & 142 & 446 & 218 & 149 & 239 & 41195 & $-3.6 \%$ \\
\hline Bay of Plenty & 66 & 140 & 410 & 199 & 189 & 234 & 5636 & $-5.3 \%$ \\
\hline Gisborne & 327 & 148 & 406 & 262 & 219 & 259 & 30890 & $-2.7 \%$ \\
\hline Manawatu-Wanganui & 936 & 123 & 440 & 209 & 146 & 229 & 78330 & $-3.3 \%$ \\
\hline Hawkes Bay & 586 & 131 & 320 & 147 & 196 & 199 & 42439 & $-2.8 \%$ \\
\hline Taranaki & 125 & 127 & 439 & 359 & 160 & 271 & 12350 & $-1.5 \%$ \\
\hline Tasman & 57 & 120 & 399 & 185 & 159 & 216 & 4490 & $-0.7 \%$ \\
\hline Marlborough & 310 & 87 & 306 & 209 & 142 & 186 & 21081 & $-0.7 \%$ \\
\hline Westland & 32 & 75 & 363 & 279 & 158 & 219 & 2532 & $-5.4 \%$ \\
\hline Wellington & 281 & 132 & 407 & 153 & 158 & 212 & 21775 & $-2.4 \%$ \\
\hline Nelson City & 2 & 112 & 393 & 186 & 134 & 206 & 186 & $-4.7 \%$ \\
\hline Canterbury & 1824 & 78 & 269 & 153 & 131 & 158 & 105037 & $-1.3 \%$ \\
\hline Otago & 1738 & 60 & 273 & 165 & 113 & 153 & 97026 & $-2.5 \%$ \\
\hline Southland & 698 & 68 & 375 & 228 & 137 & 202 & 51436 & $-3.8 \%$ \\
\hline National & 7778 & 97 & 338 & 185 & 143 & 191 & 541710 & $-2.7 \%$ \\
\hline \multicolumn{9}{|l|}{ Dairy } \\
\hline Northland & 172 & 309 & 582 & 346 & 383 & 405 & 25409 & $2.4 \%$ \\
\hline Auckland & 53 & 292 & 646 & 363 & 337 & 410 & 7886 & $2.0 \%$ \\
\hline Waikato & 487 & 262 & 642 & 381 & 334 & 405 & 71941 & $2.8 \%$ \\
\hline Bay of Plenty & 80 & 264 & 613 & 359 & 396 & 408 & 11864 & $2.1 \%$ \\
\hline Gisborne & 3 & 270 & 581 & 470 & 421 & 435 & 397 & $4.3 \%$ \\
\hline Manawatu-Wanganui & 127 & 218 & 653 & 378 & 278 & 382 & 17720 & $3.8 \%$ \\
\hline Hawkes Bay & 16 & 224 & 534 & 335 & 378 & 368 & 2111 & $5.2 \%$ \\
\hline Taranaki & 215 & 242 & 651 & 611 & 382 & 471 & 37034 & $6.0 \%$ \\
\hline Tasman & 27 & 212 & 629 & 458 & 342 & 410 & 4080 & $6.1 \%$ \\
\hline Marlborough & 9 & 204 & 552 & 360 & 307 & 356 & 1202 & $5.8 \%$ \\
\hline Westland & 52 & 161 & 581 & 516 & 346 & 401 & 7665 & $3.1 \%$ \\
\hline Wellington & 30 & 225 & 621 & 298 & 309 & 363 & 3932 & $6.6 \%$ \\
\hline Nelson City & 0.4 & 195 & 502 & 286 & 310 & 323 & 50 & $6.9 \%$ \\
\hline Canterbury & 119 & 174 & 434 & 287 & 302 & 299 & 13031 & $10.1 \%$ \\
\hline Otago & 62 & 132 & 526 & 366 & 267 & 323 & 7266 & $6.3 \%$ \\
\hline Southland & 106 & 126 & 597 & 456 & 279 & 365 & 14044 & $4.9 \%$ \\
\hline National & 1557 & 235 & 608 & 408 & 336 & 397 & 225631 & $4.1 \%$ \\
\hline Combined national & 9335 & & & & & & 767341 & $-0.8 \%$ \\
\hline
\end{tabular}


Table B9. Land-use change, $2020 \mathrm{CO}_{2}=\mathrm{NZD} 0$.

\begin{tabular}{|c|c|c|c|c|c|c|c|c|c|}
\hline \multirow[b]{2}{*}{ Region } & \multirow{2}{*}{$\begin{array}{l}\text { Area } \\
\text { (kha) }\end{array}$} & \multirow{2}{*}{$\begin{array}{r}\text { Change } \\
(\%)\end{array}$} & \multicolumn{2}{|c|}{ Winter Spring } & Summer & Autumn & \multirow[b]{2}{*}{ Average } & \multirow{2}{*}{$\begin{array}{r}\text { Total ME } \\
(\mathrm{TJ})\end{array}$} & \multirow{2}{*}{$\begin{array}{r}\text { Change } \\
(\%)\end{array}$} \\
\hline & & & Avera & ge produc & tion (MJ ha & $\left.{ }^{-1} \mathrm{~d}^{-1}\right)$ & & & \\
\hline \multicolumn{10}{|l|}{ Sheep \& beef } \\
\hline Northland & 248 & $3.9 \%$ & 138 & 423 & 295 & 198 & 263 & 23838 & $3.8 \%$ \\
\hline Auckland & 83 & $-2.4 \%$ & 129 & 446 & 305 & 168 & 262 & 7976 & $-2.2 \%$ \\
\hline Waikato & 479 & $1.4 \%$ & 112 & 421 & 371 & 201 & 276 & 48332 & $1.7 \%$ \\
\hline Bay of Plenty & 74 & $12.5 \%$ & 108 & 403 & 371 & 219 & 275 & 7444 & $13.1 \%$ \\
\hline Gisborne & 326 & $-0.4 \%$ & 106 & 431 & 322 & 200 & 265 & 31487 & $-0.3 \%$ \\
\hline Manawatu-Wanganui & 909 & $-2.9 \%$ & 91 & 414 & 373 & 185 & 266 & 88262 & $-2.9 \%$ \\
\hline Hawkes Bay & 583 & $-0.4 \%$ & 94 & 397 & 212 & 179 & 221 & 46935 & $-0.4 \%$ \\
\hline Taranaki & 123 & $-1.7 \%$ & 105 & 397 & 412 & 214 & 282 & 12618 & $-1.8 \%$ \\
\hline Tasman & 61 & $7.7 \%$ & 86 & 405 & 274 & 173 & 235 & 5259 & $8.6 \%$ \\
\hline Marlborough & 312 & $0.4 \%$ & 59 & 310 & 231 & 133 & 183 & 20827 & $0.6 \%$ \\
\hline Westland & 39 & $23.8 \%$ & 83 & 358 & 381 & 207 & 257 & 3686 & $25.0 \%$ \\
\hline Wellington & 281 & $0.0 \%$ & 95 & 440 & 249 & 156 & 235 & 24065 & $0.0 \%$ \\
\hline Nelson City & 3 & $4.0 \%$ & 87 & 413 & 269 & 142 & 228 & 214 & $3.1 \%$ \\
\hline Canterbury & 1820 & $-0.2 \%$ & 54 & 307 & 211 & 131 & 176 & 116850 & $-0.2 \%$ \\
\hline Otago & 1741 & $0.1 \%$ & 46 & 296 & 248 & 134 & 181 & 115185 & $0.2 \%$ \\
\hline Southland & 684 & $-1.9 \%$ & 62 & 375 & 370 & 175 & 246 & 61348 & $-2.1 \%$ \\
\hline National & 7766 & $-0.2 \%$ & 73 & 356 & 279 & 159 & 217 & 614327 & $-0.13 \%$ \\
\hline \multicolumn{10}{|l|}{ Dairy } \\
\hline Northland & 162 & $-5.6 \%$ & 221 & 617 & 464 & 377 & 420 & 24875 & $-5.5 \%$ \\
\hline Auckland & 54 & $2.6 \%$ & 209 & 628 & 502 & 342 & 420 & 8302 & $2.4 \%$ \\
\hline Waikato & 482 & $-1.0 \%$ & 186 & 629 & 506 & 363 & 421 & 74063 & $-1.1 \%$ \\
\hline Bay of Plenty & 71 & $-10.3 \%$ & 183 & 616 & 532 & 402 & 433 & 11299 & $-10.4 \%$ \\
\hline Gisborne & 5 & $95.0 \%$ & 182 & 569 & 472 & 377 & 400 & 712 & $85.4 \%$ \\
\hline Manawatu-Wanganui & 157 & $23.1 \%$ & 150 & 603 & 541 & 313 & 402 & 22953 & $23.4 \%$ \\
\hline Hawkes Bay & 18 & $17.3 \%$ & 136 & 582 & 422 & 330 & 368 & 2476 & $14.7 \%$ \\
\hline Taranaki & 217 & $0.9 \%$ & 168 & 595 & 615 & 394 & 443 & 35106 & $0.9 \%$ \\
\hline Tasman & 22 & $-18.0 \%$ & 142 & 586 & 549 & 358 & 409 & 3336 & $-17.5 \%$ \\
\hline Marlborough & 7 & $-20.5 \%$ & 125 & 542 & 428 & 293 & 347 & 930 & $-23.1 \%$ \\
\hline Westland & 42 & $-20.6 \%$ & 123 & 533 & 584 & 374 & 403 & 6122 & $-20.4 \%$ \\
\hline Wellington & 30 & $0.3 \%$ & 143 & 614 & 428 & 296 & 370 & 4021 & $0.1 \%$ \\
\hline Nelson City & 0 & $-41.2 \%$ & 124 & 533 & 350 & 300 & 327 & 30 & $-39.5 \%$ \\
\hline Canterbury & 121 & $1.4 \%$ & 104 & 515 & 361 & 282 & 315 & 13938 & $1.6 \%$ \\
\hline Otago & 58 & $-5.3 \%$ & 89 & 526 & 488 & 287 & 347 & 7409 & $-5.0 \%$ \\
\hline Southland & 119 & $12.3 \%$ & 93 & 529 & 566 & 334 & 381 & 16480 & $12.8 \%$ \\
\hline National & 1566 & $0.6 \%$ & 163 & 595 & 514 & 352 & 406 & 232053 & $0.45 \%$ \\
\hline Combined national & 9332 & & & & & & & 846380 & $0.03 \%$ \\
\hline
\end{tabular}


Table B10. Land-use change, $2020 \mathrm{CO}_{2}=$ NZD 50 per tonne.

\begin{tabular}{|c|c|c|c|c|c|c|c|c|c|}
\hline \multirow[b]{2}{*}{ Region } & \multirow{2}{*}{$\begin{array}{l}\text { Area } \\
\text { (kha) }\end{array}$} & \multirow{2}{*}{$\begin{array}{r}\text { Change } \\
(\%)\end{array}$} & Winter & Spring & Summer & Autumn & \multirow[b]{2}{*}{ Average } & \multirow{2}{*}{$\begin{array}{r}\text { Total ME } \\
(\mathrm{TJ})\end{array}$} & \multirow{2}{*}{$\begin{array}{r}\text { Change } \\
(\%)\end{array}$} \\
\hline & & & \multicolumn{4}{|c|}{ Average production $\left(\mathrm{MJ} \mathrm{ha}^{-1} \mathrm{~d}^{-1}\right)$} & & & \\
\hline \multicolumn{10}{|l|}{ Sheep \& beef } \\
\hline Northland & 248 & $4.0 \%$ & 138 & 423 & 295 & 198 & 263 & 23856 & $3.9 \%$ \\
\hline Auckland & 84 & $-2.0 \%$ & 129 & 446 & 305 & 168 & 262 & 8007 & $-1.8 \%$ \\
\hline Waikato & 481 & $1.7 \%$ & 112 & 421 & 371 & 201 & 276 & 48463 & $2.0 \%$ \\
\hline Bay of Plenty & 74 & $12.7 \%$ & 108 & 403 & 371 & 219 & 275 & 7455 & $13.3 \%$ \\
\hline Gisborne & 327 & $-0.2 \%$ & 106 & 431 & 322 & 200 & 265 & 31541 & $-0.1 \%$ \\
\hline Manawatu-Wanganui & 913 & $-2.4 \%$ & 91 & 414 & 373 & 185 & 266 & 88641 & $-2.4 \%$ \\
\hline Hawkes Bay & 583 & $-0.4 \%$ & 94 & 397 & 212 & 179 & 221 & 46954 & $-0.4 \%$ \\
\hline Taranaki & 123 & $-1.6 \%$ & 105 & 397 & 412 & 214 & 282 & 12638 & $-1.6 \%$ \\
\hline Tasman & 61 & $7.7 \%$ & 86 & 405 & 274 & 173 & 235 & 5259 & $8.6 \%$ \\
\hline Marlborough & 311 & $0.3 \%$ & 59 & 310 & 231 & 133 & 183 & 20820 & $0.6 \%$ \\
\hline Westland & 39 & $23.8 \%$ & 83 & 358 & 381 & 207 & 257 & 3686 & $25.0 \%$ \\
\hline Wellington & 281 & $0.0 \%$ & 95 & 440 & 249 & 156 & 235 & 24078 & $0.1 \%$ \\
\hline Nelson City & 3 & $4.0 \%$ & 87 & 413 & 269 & 142 & 228 & 214 & $3.1 \%$ \\
\hline Canterbury & 1820 & $-0.2 \%$ & 54 & 307 & 211 & 131 & 176 & 116849 & $-0.2 \%$ \\
\hline Otago & 1741 & $0.1 \%$ & 46 & 296 & 248 & 134 & 181 & 115195 & $0.2 \%$ \\
\hline Southland & 689 & $-1.2 \%$ & 62 & 375 & 370 & 176 & 246 & 61805 & $-1.4 \%$ \\
\hline National & 7777 & $0.0 \%$ & 73 & 356 & 279 & 159 & 217 & 615462 & $0.05 \%$ \\
\hline \multicolumn{10}{|l|}{ Dairy } \\
\hline Northland & 162 & $-5.8 \%$ & 221 & 617 & 464 & 377 & 420 & 24830 & $-5.7 \%$ \\
\hline Auckland & 54 & $1.8 \%$ & 209 & 628 & 502 & 342 & 420 & 8237 & $1.6 \%$ \\
\hline Waikato & 480 & $-1.3 \%$ & 186 & 629 & 506 & 363 & 421 & 73827 & $-1.4 \%$ \\
\hline Bay of Plenty & 71 & $-10.6 \%$ & 183 & 616 & 532 & 402 & 433 & 11258 & $-10.7 \%$ \\
\hline Gisborne & 4 & $63.0 \%$ & 180 & 563 & 455 & 373 & 393 & 584 & $52.0 \%$ \\
\hline Manawatu-Wanganui & 152 & $19.8 \%$ & 150 & 603 & 541 & 313 & 402 & 22322 & $20.0 \%$ \\
\hline Hawkes Bay & 18 & $16.1 \%$ & 136 & 581 & 421 & 330 & 367 & 2447 & $13.3 \%$ \\
\hline Taranaki & 217 & $0.8 \%$ & 168 & 595 & 615 & 394 & 443 & 35083 & $0.9 \%$ \\
\hline Tasman & 22 & $-18.0 \%$ & 142 & 586 & 549 & 358 & 409 & 3336 & $-17.5 \%$ \\
\hline Marlborough & 7 & $-20.5 \%$ & 125 & 542 & 428 & 293 & 347 & 930 & $-23.1 \%$ \\
\hline Westland & 42 & $-20.6 \%$ & 123 & 533 & 584 & 374 & 403 & 6122 & $-20.4 \%$ \\
\hline Wellington & 30 & $-0.3 \%$ & 143 & 614 & 428 & 296 & 370 & 3997 & $-0.5 \%$ \\
\hline Nelson City & 0 & $-41.2 \%$ & 124 & 533 & 350 & 300 & 327 & 30 & $-39.5 \%$ \\
\hline Canterbury & 120 & $0.8 \%$ & 104 & 515 & 361 & 282 & 315 & 13850 & $0.9 \%$ \\
\hline Otago & 58 & $-5.9 \%$ & 89 & 526 & 488 & 287 & 347 & 7361 & $-5.6 \%$ \\
\hline Southland & 114 & $7.7 \%$ & 93 & 530 & 566 & 334 & 381 & 15811 & $8.2 \%$ \\
\hline National & 1552 & $-0.3 \%$ & 163 & 595 & 513 & 352 & 406 & 230025 & $-0.43 \%$ \\
\hline Combined national & 9330 & & & & & & & 845487 & $-0.08 \%$ \\
\hline
\end{tabular}


Table B11. Land-use change, $2020 \mathrm{CO}_{2}=$ NZD 100 per tonne.

\begin{tabular}{|c|c|c|c|c|c|c|c|c|c|}
\hline \multirow[b]{2}{*}{ Region } & \multirow{2}{*}{$\begin{array}{l}\text { Area } \\
\text { (kha) }\end{array}$} & \multirow{2}{*}{$\begin{array}{r}\text { Change } \\
(\%)\end{array}$} & \multicolumn{2}{|c|}{ Winter Spring } & Summer & Autumn & \multirow[b]{2}{*}{ Average } & \multirow{2}{*}{$\begin{array}{r}\text { Total ME } \\
(\mathrm{TJ})\end{array}$} & \multirow{2}{*}{$\begin{array}{r}\text { Change } \\
(\%)\end{array}$} \\
\hline & & & Avera & ge produc & tion (MJ ha & $\left.{ }^{-1} \mathrm{~d}^{-1}\right)$ & & & \\
\hline \multicolumn{10}{|l|}{ Sheep \& beef } \\
\hline Northland & 249 & $4.5 \%$ & 138 & 423 & 295 & 198 & 263 & 23974 & $4.4 \%$ \\
\hline Auckland & 84 & $-1.6 \%$ & 129 & 446 & 305 & 168 & 262 & 8044 & $-1.4 \%$ \\
\hline Waikato & 485 & $2.7 \%$ & 112 & 421 & 372 & 201 & 276 & 48968 & $3.0 \%$ \\
\hline Bay of Plenty & 76 & $15.1 \%$ & 108 & 403 & 371 & 219 & 275 & 7621 & $15.8 \%$ \\
\hline Gisborne & 327 & $-0.2 \%$ & 106 & 431 & 322 & 200 & 265 & 31546 & $-0.1 \%$ \\
\hline Manawatu-Wanganui & 915 & $-2.2 \%$ & 91 & 414 & 373 & 185 & 266 & 88850 & $-2.2 \%$ \\
\hline Hawkes Bay & 584 & $-0.3 \%$ & 94 & 397 & 212 & 179 & 221 & 47003 & $-0.3 \%$ \\
\hline Taranaki & 123 & $-1.2 \%$ & 105 & 397 & 412 & 214 & 282 & 12691 & $-1.2 \%$ \\
\hline Tasman & 62 & $8.2 \%$ & 86 & 405 & 274 & 173 & 235 & 5288 & $9.2 \%$ \\
\hline Marlborough & 311 & $0.3 \%$ & 59 & 310 & 231 & 133 & 183 & 20813 & $0.5 \%$ \\
\hline Westland & 40 & $26.5 \%$ & 83 & 358 & 381 & 207 & 257 & 3766 & $27.7 \%$ \\
\hline Wellington & 281 & $0.1 \%$ & 95 & 440 & 249 & 156 & 235 & 24094 & $0.1 \%$ \\
\hline Nelson City & 3 & $4.0 \%$ & 87 & 413 & 269 & 142 & 228 & 214 & $3.1 \%$ \\
\hline Canterbury & 1819 & $-0.3 \%$ & 54 & 307 & 211 & 131 & 176 & 116801 & $-0.2 \%$ \\
\hline Otago & 1740 & $0.1 \%$ & 47 & 296 & 248 & 134 & 181 & 115184 & $0.2 \%$ \\
\hline Southland & 689 & $-1.2 \%$ & 62 & 375 & 370 & 176 & 246 & 61827 & $-1.3 \%$ \\
\hline National & 7789 & $0.1 \%$ & 73 & 356 & 279 & 159 & 217 & 616684 & $0.25 \%$ \\
\hline \multicolumn{10}{|l|}{ Dairy } \\
\hline Northland & 161 & $-6.5 \%$ & 221 & 617 & 464 & 377 & 420 & 24633 & $-6.5 \%$ \\
\hline Auckland & 53 & $1.0 \%$ & 209 & 628 & 502 & 342 & 420 & 8180 & $0.9 \%$ \\
\hline Waikato & 475 & $-2.3 \%$ & 186 & 629 & 505 & 363 & 421 & 73025 & $-2.5 \%$ \\
\hline Bay of Plenty & 70 & $-12.7 \%$ & 184 & 616 & 531 & 402 & 433 & 10994 & $-12.8 \%$ \\
\hline Gisborne & 4 & $61.0 \%$ & 180 & 563 & 452 & 372 & 392 & 576 & $49.8 \%$ \\
\hline Manawatu-Wanganui & 150 & $18.0 \%$ & 150 & 603 & 541 & 312 & 402 & 21999 & $18.3 \%$ \\
\hline Hawkes Bay & 18 & $12.6 \%$ & 137 & 582 & 419 & 330 & 367 & 2370 & $9.8 \%$ \\
\hline Taranaki & 216 & $0.5 \%$ & 169 & 595 & 615 & 394 & 443 & 34961 & $0.5 \%$ \\
\hline Tasman & 22 & $-19.1 \%$ & 142 & 586 & 549 & 358 & 409 & 3290 & $-18.6 \%$ \\
\hline Marlborough & 7 & $-21.9 \%$ & 125 & 542 & 428 & 293 & 347 & 915 & $-24.4 \%$ \\
\hline Westland & 41 & $-22.5 \%$ & 123 & 533 & 585 & 374 & 404 & 5978 & $-22.3 \%$ \\
\hline Wellington & 29 & $-0.8 \%$ & 143 & 615 & 427 & 296 & 370 & 3973 & $-1.1 \%$ \\
\hline Nelson City & 0 & $-41.2 \%$ & 124 & 533 & 350 & 300 & 327 & 30 & $-39.5 \%$ \\
\hline Canterbury & 120 & $0.3 \%$ & 104 & 515 & 361 & 282 & 315 & 13788 & $0.5 \%$ \\
\hline Otago & 58 & $-6.2 \%$ & 89 & 526 & 488 & 287 & 347 & 7331 & $-6.0 \%$ \\
\hline Southland & 113 & $7.4 \%$ & 93 & 530 & 566 & 334 & 381 & 15761 & $7.9 \%$ \\
\hline National & 1537 & $-1.3 \%$ & 163 & 595 & 513 & 352 & 406 & 227802 & $-1.39 \%$ \\
\hline Combined national & 9326 & & & & & & & 844486 & $-0.20 \%$ \\
\hline
\end{tabular}


Table B12. Land-use change, $2050 \mathrm{CO}_{2}=\mathrm{NZD} 0$.

\begin{tabular}{|c|c|c|c|c|c|c|c|c|c|}
\hline \multirow[b]{2}{*}{ Region } & \multirow{2}{*}{$\begin{array}{l}\text { Area } \\
\text { (kha) }\end{array}$} & \multirow{2}{*}{$\begin{array}{r}\text { Change } \\
(\%)\end{array}$} & Winter & Spring & Summer & Autumn & \multirow[b]{2}{*}{ Average } & \multirow{2}{*}{$\begin{array}{r}\text { Total ME } \\
(\mathrm{TJ})\end{array}$} & \multirow{2}{*}{$\begin{array}{r}\text { Change } \\
(\%)\end{array}$} \\
\hline & & & \multicolumn{4}{|c|}{ Average production $\left(\mathrm{MJ} \mathrm{ha}^{-1} \mathrm{~d}^{-1}\right)$} & & & \\
\hline \multicolumn{10}{|l|}{ Sheep \& beef } \\
\hline Northland & 243 & $1.7 \%$ & 138 & 423 & 295 & 198 & 264 & 23337 & $1.6 \%$ \\
\hline Auckland & 78 & $-8.2 \%$ & 129 & 446 & 306 & 168 & 262 & 7514 & $-7.9 \%$ \\
\hline Waikato & 468 & $-1.1 \%$ & 111 & 421 & 373 & 202 & 277 & 47192 & $-0.7 \%$ \\
\hline Bay of Plenty & 72 & $9.5 \%$ & 107 & 403 & 372 & 219 & 275 & 7246 & $10.1 \%$ \\
\hline Gisborne & 319 & $-2.4 \%$ & 105 & 432 & 324 & 200 & 265 & 30918 & $-2.1 \%$ \\
\hline Manawatu-Wanganui & 866 & $-7.4 \%$ & 91 & 413 & 373 & 186 & 266 & 84111 & $-7.4 \%$ \\
\hline Hawkes Bay & 572 & $-2.3 \%$ & 94 & 397 & 213 & 179 & 221 & 46074 & $-2.2 \%$ \\
\hline Taranaki & 116 & $-6.9 \%$ & 104 & 396 & 412 & 214 & 282 & 11946 & $-7.0 \%$ \\
\hline Tasman & 59 & $3.8 \%$ & 86 & 405 & 275 & 173 & 235 & 5070 & $4.7 \%$ \\
\hline Marlborough & 308 & $-0.9 \%$ & 59 & 310 & 231 & 133 & 183 & 20564 & $-0.7 \%$ \\
\hline Westland & 38 & $20.6 \%$ & 83 & 358 & 381 & 207 & 257 & 3593 & $21.8 \%$ \\
\hline Wellington & 268 & $-4.8 \%$ & 95 & 439 & 251 & 156 & 235 & 22960 & $-4.6 \%$ \\
\hline Nelson City & 3 & $1.0 \%$ & 87 & 414 & 271 & 142 & 228 & 208 & $0.3 \%$ \\
\hline Canterbury & 1711 & $-6.2 \%$ & 53 & 303 & 212 & 130 & 175 & 109073 & $-6.8 \%$ \\
\hline Otago & 1718 & $-1.2 \%$ & 46 & 295 & 248 & 134 & 181 & 113356 & $-1.4 \%$ \\
\hline Southland & 627 & $-10.2 \%$ & 61 & 373 & 367 & 174 & 244 & 55748 & $-11.0 \%$ \\
\hline National & 7465 & $-4.0 \%$ & 73 & 354 & 279 & 159 & 216 & 588911 & $-4.26 \%$ \\
\hline \multicolumn{10}{|l|}{ Dairy } \\
\hline Northland & 168 & $-2.5 \%$ & 222 & 617 & 465 & 377 & 420 & 25715 & $-2.4 \%$ \\
\hline Auckland & 59 & $11.2 \%$ & 209 & 628 & 502 & 341 & 420 & 8991 & $10.9 \%$ \\
\hline Waikato & 495 & $1.7 \%$ & 186 & 629 & 506 & 363 & 421 & 76051 & $1.5 \%$ \\
\hline Bay of Plenty & 75 & $-6.5 \%$ & 183 & 615 & 532 & 401 & 433 & 11772 & $-6.7 \%$ \\
\hline Gisborne & 12 & $390.0 \%$ & 179 & 574 & 440 & 370 & 390 & 1746 & $354.5 \%$ \\
\hline Manawatu-Wanganui & 203 & $59.6 \%$ & 149 & 603 & 545 & 313 & 403 & 29830 & $60.4 \%$ \\
\hline Hawkes Bay & 30 & $89.7 \%$ & 137 & 578 & 392 & 325 & 358 & 3899 & $80.6 \%$ \\
\hline Taranaki & 226 & $4.8 \%$ & 168 & 595 & 614 & 393 & 443 & 36456 & $4.8 \%$ \\
\hline Tasman & 25 & $-8.3 \%$ & 142 & 587 & 539 & 353 & 405 & 3696 & $-8.6 \%$ \\
\hline Marlborough & 9 & $-6.5 \%$ & 123 & 538 & 404 & 283 & 337 & 1064 & $-12.1 \%$ \\
\hline Westland & 42 & $-20.1 \%$ & 123 & 533 & 584 & 374 & 404 & 6164 & $-19.8 \%$ \\
\hline Wellington & 43 & $46.5 \%$ & 141 & 614 & 417 & 294 & 367 & 5815 & $44.8 \%$ \\
\hline Nelson City & 0 & $-41.2 \%$ & 124 & 533 & 350 & 300 & 327 & 30 & $-39.5 \%$ \\
\hline Canterbury & 221 & $85.0 \%$ & 103 & 520 & 361 & 278 & 315 & 25417 & $85.2 \%$ \\
\hline Otago & 78 & $26.6 \%$ & 89 & 526 & 482 & 284 & 345 & 9838 & $26.1 \%$ \\
\hline Southland & 176 & $67.1 \%$ & 94 & 532 & 568 & 334 & 382 & 24593 & $68.3 \%$ \\
\hline National & 1861 & $19.5 \%$ & 157 & 589 & 506 & 345 & 399 & 271076 & $17.34 \%$ \\
\hline Combined national & 9326 & & & & & & & 859987 & $1.64 \%$ \\
\hline
\end{tabular}


Table B13. Land-use change, $2050 \mathrm{CO}_{2}=$ NZD 50 per tonne.

\begin{tabular}{|c|c|c|c|c|c|c|c|c|c|}
\hline \multirow[b]{2}{*}{ Region } & \multirow{2}{*}{$\begin{array}{l}\text { Area } \\
\text { (kha) }\end{array}$} & \multirow{2}{*}{$\begin{array}{r}\text { Change } \\
(\%)\end{array}$} & \multicolumn{2}{|c|}{ Winter Spring } & Summer & Autumn & \multirow[b]{2}{*}{ Average } & \multirow{2}{*}{$\begin{array}{r}\text { Total ME } \\
(\mathrm{TJ})\end{array}$} & \multirow{2}{*}{$\begin{array}{r}\text { Change } \\
(\%)\end{array}$} \\
\hline & & & Avera & ge produc & tion (MJ ha & $\left.{ }^{-1} \mathrm{~d}^{-1}\right)$ & & & \\
\hline \multicolumn{10}{|l|}{ Sheep \& beef } \\
\hline Northland & 243 & $1.9 \%$ & 138 & 423 & 295 & 198 & 264 & 23385 & $1.8 \%$ \\
\hline Auckland & 79 & $-7.5 \%$ & 129 & 446 & 306 & 168 & 262 & 7569 & $-7.2 \%$ \\
\hline Waikato & 469 & $-0.9 \%$ & 111 & 421 & 372 & 202 & 276 & 47283 & $-0.5 \%$ \\
\hline Bay of Plenty & 72 & $9.9 \%$ & 107 & 403 & 372 & 219 & 275 & 7272 & $10.5 \%$ \\
\hline Gisborne & 319 & $-2.4 \%$ & 105 & 432 & 324 & 200 & 265 & 30920 & $-2.1 \%$ \\
\hline Manawatu-Wanganui & 867 & $-7.3 \%$ & 91 & 413 & 373 & 186 & 266 & 84201 & $-7.3 \%$ \\
\hline Hawkes Bay & 572 & $-2.4 \%$ & 94 & 397 & 213 & 179 & 221 & 46069 & $-2.2 \%$ \\
\hline Taranaki & 117 & $-6.4 \%$ & 104 & 397 & 412 & 215 & 282 & 12013 & $-6.5 \%$ \\
\hline Tasman & 59 & $3.9 \%$ & 86 & 405 & 275 & 173 & 235 & 5075 & $4.8 \%$ \\
\hline Marlborough & 308 & $-0.8 \%$ & 59 & 310 & 231 & 133 & 183 & 20573 & $-0.6 \%$ \\
\hline Westland & 38 & $21.0 \%$ & 83 & 359 & 381 & 207 & 257 & 3603 & $22.2 \%$ \\
\hline Wellington & 268 & $-4.6 \%$ & 95 & 439 & 251 & 156 & 235 & 22986 & $-4.5 \%$ \\
\hline Nelson City & 3 & $1.0 \%$ & 87 & 414 & 271 & 142 & 228 & 208 & $0.3 \%$ \\
\hline Canterbury & 1716 & $-5.9 \%$ & 53 & 304 & 211 & 130 & 175 & 109353 & $-6.6 \%$ \\
\hline Otago & 1719 & $-1.1 \%$ & 46 & 295 & 248 & 134 & 181 & 113412 & $-1.4 \%$ \\
\hline Southland & 627 & $-10.1 \%$ & 61 & 373 & 367 & 174 & 244 & 55772 & $-11.0 \%$ \\
\hline National & 7475 & $-3.9 \%$ & 73 & 354 & 279 & 159 & 216 & 589695 & $-4.13 \%$ \\
\hline \multicolumn{10}{|l|}{ Dairy } \\
\hline Northland & 167 & $-3.1 \%$ & 222 & 617 & 465 & 377 & 420 & 25557 & $-3.0 \%$ \\
\hline Auckland & 58 & $9.8 \%$ & 209 & 628 & 502 & 341 & 420 & 8878 & $9.6 \%$ \\
\hline Waikato & 494 & $1.4 \%$ & 186 & 629 & 506 & 363 & 421 & 75862 & $1.3 \%$ \\
\hline Bay of Plenty & 74 & $-6.8 \%$ & 183 & 615 & 532 & 401 & 433 & 11730 & $-7.0 \%$ \\
\hline Gisborne & 12 & $389.0 \%$ & 178 & 573 & 439 & 370 & 390 & 1741 & $353.4 \%$ \\
\hline Manawatu-Wanganui & 202 & $58.7 \%$ & 149 & 603 & 546 & 313 & 403 & 29672 & $59.6 \%$ \\
\hline Hawkes Bay & 30 & $89.2 \%$ & 137 & 578 & 392 & 325 & 358 & 3888 & $80.1 \%$ \\
\hline Taranaki & 225 & $4.4 \%$ & 168 & 595 & 614 & 393 & 443 & 36309 & $4.4 \%$ \\
\hline Tasman & 25 & $-8.9 \%$ & 142 & 587 & 539 & 353 & 405 & 3673 & $-9.2 \%$ \\
\hline Marlborough & 8 & $-9.2 \%$ & 123 & 541 & 410 & 286 & 340 & 1043 & $-13.8 \%$ \\
\hline Westland & 42 & $-20.4 \%$ & 123 & 533 & 584 & 374 & 403 & 6133 & $-20.2 \%$ \\
\hline Wellington & 43 & $45.4 \%$ & 141 & 614 & 417 & 294 & 367 & 5771 & $43.7 \%$ \\
\hline Nelson City & 0 & $-41.2 \%$ & 124 & 533 & 350 & 300 & 327 & 30 & $-39.5 \%$ \\
\hline Canterbury & 216 & $80.9 \%$ & 103 & 520 & 363 & 278 & 316 & 24912 & $81.5 \%$ \\
\hline Otago & 77 & $24.7 \%$ & 89 & 527 & 484 & 285 & 346 & 9721 & $24.6 \%$ \\
\hline Southland & 176 & $66.8 \%$ & 94 & 532 & 568 & 334 & 382 & 24542 & $68.0 \%$ \\
\hline National & 1848 & $18.7 \%$ & 157 & 589 & 506 & 345 & 399 & 269462 & $16.64 \%$ \\
\hline Combined national & 9323 & & & & & & & 859157 & $1.54 \%$ \\
\hline
\end{tabular}


Table B14. Land-use change, $2050 \mathrm{CO}_{2}=$ NZD 100 per tonne.

\begin{tabular}{|c|c|c|c|c|c|c|c|c|c|}
\hline \multirow[b]{2}{*}{ Region } & \multirow{2}{*}{$\begin{array}{l}\text { Area } \\
\text { (kha) }\end{array}$} & \multirow{2}{*}{$\begin{array}{r}\text { Change } \\
(\%)\end{array}$} & \multicolumn{2}{|c|}{ Winter Spring } & Summer & Autumn & \multirow[b]{2}{*}{ Average } & \multirow{2}{*}{$\begin{array}{r}\text { Total ME } \\
(\mathrm{TJ})\end{array}$} & \multirow{2}{*}{$\begin{array}{r}\text { Change } \\
(\%)\end{array}$} \\
\hline & & & Avera & ge produc & tion $\left(\mathrm{MJ} \mathrm{ha}^{-}\right.$ & $\left.-1 d^{-1}\right)$ & & & \\
\hline \multicolumn{10}{|l|}{ Sheep \& beef } \\
\hline Northland & 244 & $2.3 \%$ & 138 & 423 & 295 & 198 & 264 & 23471 & $2.2 \%$ \\
\hline Auckland & 79 & $-7.3 \%$ & 129 & 446 & 306 & 168 & 262 & 7585 & $-7.0 \%$ \\
\hline Waikato & 473 & $0.2 \%$ & 111 & 421 & 373 & 202 & 277 & 47776 & $0.5 \%$ \\
\hline Bay of Plenty & 74 & $12.3 \%$ & 107 & 403 & 372 & 219 & 275 & 7436 & $13.0 \%$ \\
\hline Gisborne & 319 & $-2.4 \%$ & 105 & 432 & 324 & 200 & 265 & 30926 & $-2.1 \%$ \\
\hline Manawatu-Wanganui & 870 & $-7.1 \%$ & 91 & 413 & 373 & 186 & 266 & 84413 & $-7.1 \%$ \\
\hline Hawkes Bay & 572 & $-2.3 \%$ & 94 & 397 & 213 & 179 & 221 & 46102 & $-2.2 \%$ \\
\hline Taranaki & 117 & $-6.0 \%$ & 104 & 397 & 412 & 215 & 282 & 12065 & $-6.1 \%$ \\
\hline Tasman & 59 & $4.3 \%$ & 86 & 405 & 275 & 174 & 235 & 5095 & $5.2 \%$ \\
\hline Marlborough & 308 & $-0.9 \%$ & 59 & 310 & 231 & 133 & 183 & 20554 & $-0.7 \%$ \\
\hline Westland & 39 & $24.0 \%$ & 83 & 359 & 381 & 207 & 257 & 3696 & $25.3 \%$ \\
\hline Wellington & 268 & $-4.7 \%$ & 95 & 439 & 251 & 156 & 235 & 22983 & $-4.5 \%$ \\
\hline Nelson City & 3 & $1.0 \%$ & 87 & 414 & 271 & 142 & 228 & 208 & $0.3 \%$ \\
\hline Canterbury & 1716 & $-5.9 \%$ & 53 & 304 & 211 & 130 & 175 & 109353 & $-6.6 \%$ \\
\hline Otago & 1719 & $-1.1 \%$ & 46 & 295 & 248 & 134 & 181 & 113419 & $-1.4 \%$ \\
\hline Southland & 627 & $-10.1 \%$ & 61 & 373 & 367 & 174 & 244 & 55811 & $-10.9 \%$ \\
\hline National & 7487 & $-3.7 \%$ & 73 & 354 & 279 & 159 & 216 & 590893 & $-3.94 \%$ \\
\hline \multicolumn{10}{|l|}{ Dairy } \\
\hline Northland & 165 & $-3.9 \%$ & 222 & 617 & 465 & 377 & 420 & 25359 & $-3.7 \%$ \\
\hline Auckland & 58 & $9.1 \%$ & 209 & 628 & 502 & 341 & 420 & 8818 & $8.8 \%$ \\
\hline Waikato & 488 & $0.3 \%$ & 186 & 629 & 505 & 363 & 421 & 75035 & $0.2 \%$ \\
\hline Bay of Plenty & 73 & $-8.8 \%$ & 183 & 615 & 530 & 401 & 433 & 11478 & $-9.0 \%$ \\
\hline Gisborne & 12 & $386.0 \%$ & 179 & 573 & 438 & 370 & 390 & 1729 & $350.2 \%$ \\
\hline Manawatu-Wanganui & 200 & $57.0 \%$ & 149 & 603 & 545 & 313 & 403 & 29341 & $57.8 \%$ \\
\hline Hawkes Bay & 29 & $85.7 \%$ & 137 & 578 & 391 & 325 & 358 & 3811 & $76.6 \%$ \\
\hline Taranaki & 224 & $4.1 \%$ & 168 & 595 & 614 & 393 & 443 & 36218 & $4.1 \%$ \\
\hline Tasman & 25 & $-10.0 \%$ & 142 & 587 & 538 & 353 & 405 & 3626 & $-10.3 \%$ \\
\hline Marlborough & 8 & $-10.5 \%$ & 123 & 541 & 410 & 286 & 340 & 1028 & $-15.1 \%$ \\
\hline Westland & 41 & $-22.3 \%$ & 123 & 533 & 585 & 374 & 404 & 5989 & $-22.1 \%$ \\
\hline Wellington & 43 & $44.9 \%$ & 141 & 614 & 417 & 294 & 367 & 5750 & $43.2 \%$ \\
\hline Nelson City & 0 & $-41.2 \%$ & 124 & 533 & 350 & 300 & 327 & 30 & $-39.5 \%$ \\
\hline Canterbury & 215 & $80.4 \%$ & 103 & 520 & 363 & 278 & 316 & 24844 & $81.0 \%$ \\
\hline Otago & 77 & $24.3 \%$ & 89 & 527 & 484 & 285 & 346 & 9690 & $24.2 \%$ \\
\hline Southland & 176 & $66.4 \%$ & 94 & 532 & 568 & 334 & 382 & 24485 & $67.6 \%$ \\
\hline National & 1833 & $17.7 \%$ & 157 & 590 & 506 & 345 & 399 & 267232 & $15.68 \%$ \\
\hline Combined national & 9320 & & & & & & & 858125 & $1.42 \%$ \\
\hline
\end{tabular}


Acknowledgements. This work was supported by the New Zealand Ministry for Primary Industries (MPI) and public research funding from the Government of New Zealand (GNS-540GCT81). Pasture production data provided by Collier Isaacs (Landcorp), Brenda Rosser (Landcare Research/GNS Science), Beef + Lamb New Zealand, DairyNZ, and AgResearch. Meteorological VCSN data provided by NIWA. We thank Duncan Smeaton (AgResearch), Anne-Gaelle Ausseil (Landcare Research), William Power (GNS Science) and Wei Zhang (Motu/MPI) for their contributions. Discussion with MPI has improved the final presentation of our results. We thank two anonymous referees whose comments have improved this manuscript.

Edited by: J. Williams

\section{References}

Ainsworth, E. A. and Long, S. P.: What have we learned from 15 years of free-air $\mathrm{CO}_{2}$ enrichment (FACE)? A meta-analytic review of the responses of photosynthesis, canopy properties and plant production to rising $\mathrm{CO}_{2}$, New Phytol., 165, 351-371, 2005.

Allen, R. G., Pereira, L. S., Raes, D., and Smith, M.: Crop evapotranspiration - Guidelines for computing crop water requirements - FAO Irrigation and drainage paper 56, Food and Agriculture Organization of the United Nations, Rome, Italy, 1998.

Baisden, W. T.: Agricultural and forest productivity for modelling policy scenarios: evaluating approaches for New Zealand greenhouse gas mitigation, J. Roy. Soc. New Zealand, 36, 1-15, 2006.

Baisden, W. T., Keller, E. D., Timar, L., Smeaton, D., Clark, A., Ausseil, A., Power, W. L., and Zhang, W.: New Zealand's pasture production in 2020 and 2050, GNS Science consultancy report 2010/154, New Zealand Ministry for Primary Industries, Wellington, New Zealand, 2010.

Bala, G., Caldeira, K., Wickett, M., Phillips, T. J., Lobell, D. B., Delire, C., and Mirin, A.: Combined climate and carbon-cycle effects of large-scale deforestation, P. Natl. Acad. Sci. USA, 104, 6550-6555, 2007.

Beer, C., Reichstein, M., Tomelleri, E., Ciais, P., Jung, M., Carvalhais, N., and Papale, D.: Terrestrial gross carbon dioxide uptake: global distribution and covariation with climate, Science, 329, 834-838, 2010.

Beets, P. N. and Oliver, G. R.: Water use by managed stands of Pinus radiata, indigenous podocarp/hardwood forest, and improved pasture in the Central North Island of New Zealand, New Zeal. J. For. Sci., 37, 306-323, 2007.

Bondeau, A., Smith, P. C., Zaehle, S., Schaphoff, S., Lucht, W., Cramer, W., Gerten, D., Lotze-Campen, H., Muller, C., Reichstein, M., and Smith, B.: Modelling the role of agriculture for the 20th century global terrestrial carbon balance, Glob. Change Biol., 13, 679-706, doi:10.1111/j.13652486.2006.01305.x, 2007.

Bond-Lamberty, B., Gower, S. T., Ahl, D. E., and Thornton, P. E.: Reimplementation of the Biome-BGC model to simulate successional change, Tree Physiol., 25, 413-424, 2005.

Clark, A., Mullan, B., and Porteous, A.: Scenarios of regional drought under climate change, NIWA report number WLG201032, New Zealand Ministry for Primary Industries, Wellington, New Zealand, 2011.
Clarke-Hill, W. J. and Fraser, T. J.: PasturePlan ${ }^{\mathrm{TM}}$ : On-farm pasture growth and quality data for sheep and beef farms throughout New Zealand, New Zealand Grassland Association Conference Proceedings, Vol. 69, 2007.

DairyNZ: DairyNZ Farmwatch - Waikato, available at: http:// farmwatch.dairynz.co.nz/Home/ShowData/2\#table (last access: 21 August 2014), 2011.

de Graaf, M. A., Van Groenigen, K. J., Six, J., Hungate, B., and Van Kessel, C.: Interactions between plant growth and soil nutrient cycling under elevated $\mathrm{CO}_{2}$ : a meta-analysis, Glob. Change Biol., 12, 2077-2091, doi:10.1111/j.1365-2486.2006.01240.x, 2006.

Deser, C., Phillips, A., Bourdette, V., and Teng, H.: Uncertainty in climate change projections: the role of internal variability, Clim. Dynam., 38, 527-546, doi:10.1007/s00382-010-0977-x, 2012.

Di Vittorio, A. V., Anderson, R. S., White, J. D., Miller, N. L., and Running, S. W.: Development and optimization of an Agro-BGC ecosystem model for C4 perennial grasses, Ecol. Model., 221, 2038-2053, 2010.

Doherty, J.: PEST: Model Independent Parameter Estimation User Manual, 5th ed., Watermark Numerical Computing, Brisbane, Australia, 2005.

ENSEMBLES: ENSEMBLES RT2A Results, available at: http: //www.cnrm.meteo.fr/ensembles/public/results/results.html (last access: 3 April 2014), 2009.

ESRI: ArcGIS Desktop Release 9.3, ESRI Environmental Systems Research Institute, Redlands, California, USA, 2009.

Gerten, D., Rost, S., von Bloh, W., and Lucht, W.: Causes of change in 20th century global river discharge, Geophys. Res. Lett., 35, L20405, doi:10.1029/2008GL035258, 2008.

Gumpenberger, M., Vohland, K., Heyder, U., Poulter, B., Macey, K., Rammig, A., and Cramer, W.: Predicting pan-tropical climate change induced forest stock gains and losses - implications for REDD, Environ. Res. Lett., 5, 014013, doi:10.1088/17489326/5/1/014013, 2010.

Hendy, J., Kerr S., and Baisden, W. T.: The Land Use in Rural New Zealand Model Version 1 (LURNZv1): Model Description, Motu Working Paper 07-07, Motu Economic and Public Policy Research, Wellington, New Zealand, available at: http://www.motu.org.nz/publications/detail/the_land_use_in_ rural_new_zealand_model_version_1 (last access: 7 May 2014), 2007.

Hendy, J., Kerr, S., and Baisden, W. T.: Greenhouse gas emissions charges and credits on agricultural land: what can a model tell us?, in: Clean development mechanism and law, first edition, edited by: Lakshmi, L., Icfai University Press, Hyderabad, India, 198-209, 2008.

Hidy, D., Barcza, Z., Haszpra, L., Churkina, G., Pintér, K., and Nagy, Z.: Development of the Biome-BGC model for simulation of managed herbaceous ecosystems, Ecol. Model., 226, 99-119, doi:10.1016/j.ecolmodel.2011.11.008, 2012.

Jung, M., Le Maire, G., Zaehle, S., Luyssaert, S., Vetter, M., Churkina, G., Ciais, P., Viovy, N., and Reichstein, M.: Assessing the ability of three land ecosystem models to simulate gross carbon uptake of forests from boreal to Mediterranean climate in $\mathrm{Eu}-$ rope, Biogeosciences, 4, 647-656, doi:10.5194/bg-4-647-2007, 2007.

Keating, B. A., Carberry, P. S., Hammer, G. L., Probert, M. E., Robertson, M. J., Holzworth, D., Huth, N. I., Hargreaves, J. N. 
G., Meinke, H., Hochman, Z., McLean, G., Verburg, K., Snow, V., Dimes, J. P., Silburn, M., Wang, E., Brown, S., Bristow, K. L., Asseng, S., Chapman, S., McCown, R. L., Freebairn, D. M., and Smith, C. J.: An overview of APSIM, a model designed for farming systems simulation, Eur. J. Agron., 18, 267-288, 2003.

Keller, E. D.: Using the Biome-BGC Model to assess New Zealand's production of animal products from 2006/7 to 2011/12 seasons relative to historical averages, GNS Science consultancy letter report 2012/177LR, New Zealand Ministry for Primary Industries, Wellington, New Zealand, 2012.

Kerr, S., Anastasiadis, S., Olssen, A., Power, W., Timar, L., and Zhang, W.: Spatial and Temporal Responses to an Emissions Trading Scheme Covering Agriculture and Forestry: Simulation Results from New Zealand, Forests, 3, 1133-1156, doi:10.3390/f3041133, 2012.

Kirschbaum, M. U. F., Whitehead, D., Dean, S. M., Beets, P. N., Shepherd, J. D., and Ausseil, A.-G. E.: Implications of albedo changes following afforestation on the benefits of forests as carbon sinks, Biogeosciences, 8, 3687-3696, doi:10.5194/bg-83687-2011, 2011.

Landcare Research: Fundamental Data Layers (FDLs) Soils, available at: http://soils.landcareresearch.co.nz/ contents/SoilData_FSL_About.aspx?currentPage=SoilData_ FSL\&menuItem=SoilData, last access: 7 May 2014.

Legendre, P.: lmodel2: Model II Regression, R package version 1.7-2, available at: http://CRAN.R-project.org/package= lmodel2, last access: 21 August 2014.

Mullan, B., Porteous, A., Wratt, D., and Hollis, M.: Changes in drought risk with climate change, NIWA client report WLG200523, Ministry for the Environment, Wellington, New Zealand, available at: http://www.mfe.govt.nz/publications/climate/ drought-risk-may05/index.html (last access: 7 May 2014), 2005.

Nakicenovic, N. and Swart, R. (Eds.): Special Report on Emissions Scenarios, A Special Report of Working Group III of the Intergovernmental Panel on Climate Change, Cambridge University Press, Cambridge, United Kingdom and New York, NY, USA, available at: http://www.ipcc.ch/ipccreports/sres/emission/index. php?idp=0 (last access: 22 August 2014), 2000.

Newton, P. C., Lieffering, M., Bowatte, W. S. D., Brock, S. C., Hunt, C. L., Theobald, P. W., and Ross, D. J.: The rate of progression and stability of progressive nitrogen limitation at elevated atmospheric $\mathrm{CO}_{2}$ in a grazed grassland over 11 years of Free Air $\mathrm{CO}_{2}$ enrichment, Plant Soil, 336, 433-441, 2010.

New Zealand Ministry for the Environment: New Zealand's Fifth National Communication under the United Nations Framework Convention on Climate Change, New Zealand Ministry for the Environment, Wellington, New Zealand, available at: http://www.mfe.govt.nz/publications/climate/ nz-fifth-national-communication/ (last access: 7 May 2014), 2009.

New Zealand Ministry for the Environment: New Zealand's Greenhouse Gas Inventory 1990-2011, MfE Publication number ME 1113, Submission to the United Nations Framework Convention on Climate Change, 12 April 2013.

New Zealand Ministry for Primary Industries: Situation and Outlook for Primary Industries (SOPI) 2012, New Zealand Ministry for Primary Industries, Wellington, New Zealand, available at: http://www.mpi.govt.nz/news-resources/publications (last access: 7 May 2014), 2012.
Parfitt, R. L., Schipper, L. A., Baisden, W. T., and Elliott, A. H.: Nitrogen inputs and outputs for New Zealand in 2001 at national and regional scales, Biogeochemistry, 80, 71-88, 2006.

Parfitt, R. L., Baisden, W. T., Schipper, L. A., and Mackay, A. D.: Nitrogen inputs and outputs for New Zealand at national and regional scales: past, present and future, J. Roy. Soc. New Zeal., 38, 71-87, 2008.

Pietsch, S. A., Hasenauer, H., and Thornton, P. E.: BGC-model parameters for tree species growing in central European forests, Forest Ecol. Manag., 211, 264-295, 2005.

R Core Team: R: A language and environment for statistical computing, R Foundation for Statistical Computing, Vienna, Austria, available at: http://www.R-project.org/ (last access: $21 \mathrm{Au}-$ gust 2014), 2013.

Renwick, J., Mullan, B., Wilcocks, L., Zammit, C., Baisden, W. T., Keller, E. D., Kirschbaum, M., Meason, D., Harrison, D., Verkerk, G., Cooke, A., Marshall, P., and Clark, A.: Four Degrees of Global Warming: effects on the New Zealand primary sector, NIWA client report WLG2012-24, New Zealand Ministry for Primary Industries, Wellington, New Zealand, available at: http://www.mpi.govt.nz/news-resources/publications (last access: 7 May 2014), 2013.

Rockström, J., Falkenmark, M., Karlberg, L., Hoff, H., Rost, S., and Gerten, D.: Future water availability for global food production: the potential of green water for increasing resilience to global change, Water Resour. Res., 45, W00A12, doi:10.1029/2007WR006767, 2009.

Ronneberger, K., Criscuolo, L., Knorr, W., and Tol, R. S.: KLUM@ LPJ: Integrating dynamic land-use decisions into a dynamic global vegetation and crop growth model to assess the impacts of a changing climate. A feasibility study for Europe, Working Papers FNU-113, Research unit Sustainability and Global Change, Hamburg University, Germany, 2006.

Rosser, B. J. and Ross, C. W.: Recovery of pasture production and soil properties on soil slip scars in erodible siltstone hill country, Wairarapa, New Zealand, New Zeal. J. Agr. Res., 54, 23-44, 2011.

Rost, S., Gerten, D., Hoff, H., Lucht, W., Falkenmark, M., and Rockström, J.: Global potential to increase crop production through water management in rainfed agriculture, Environ. Res. Lett., 4, 044002, doi:10.1088/1748-9326/4/4/044002, 2009.

Roudier, P., Sultan, B., Quirion, P., and Berg, A.: The impact of future climate change on West African crop yields: What does the recent literature say?, Global Environ. Chang., 21, 1073-1083, 2011.

Schilling, C., Zuccollo, J., and Nixon, C.: Dairy's role in sustaining New Zealand: the sector's contribution to the economy, The New Zealand Institute for Economic Research, Wellington, New Zealand, available at: http://nzier.org.nz/ publications/dairys-role-in-sustaining-new-zealand (last access: 7 May 2014), 2010.

Smith, L. C., Moss, R. A., Morton, J. D., Metherell, A. K., and Fraser, T. J.: Pasture production from a long-term fertiliser trial under irrigation, New Zeal. J. Agr. Res., 55, 105-117, 2012.

South Island Dairying Development Centre: LU Dairy Farm Weekly Data, available at: http://www.siddc.org.nz/ lu-dairy-farm/weekly-data/, last access: 21 August 2014.

Stroombergen, A., Stojanovik, A., Wratt, D., Mullan, B., Tait, A., Woods, R., Baisden, W. T., Giltrap, D., Lock, K., Hendy, 
J., and Kerr, S.: Costs and benefits of climate change and adaptation to climate change in New Zealand agriculture: what do we know so far?, New Zealand Ministry of Agriculture and Forestry, Wellington, New Zealand, available at: http://www.motu.org.nz/publications/detail/costs_and_benefits_ of_climate_change_and_adaptation_to_climate_change_in_ne (last access: 7 May 2014), 2008.

Tait, A., Henderson, R., Turner, R., and Zheng, X. G.: Thin plate smoothing spline interpolation of daily rainfall for New Zealand using a climatological rainfall surface, Int. J. Climatol., 26, 2097-2115, 2006.

Thornton, P. E.: Description of a numerical simulation model for predicting the dynamics of energy, water, carbon, and nitrogen in a terrestrial ecosystem, Ph.D. thesis, University of Montana, Missoula, USA, 280 pp., 1998.

Thornton, P. E. and Rosenbloom, N. A.: Ecosystem model spin-up: Estimating steady state conditions in a coupled terrestrial carbon and nitrogen cycle model, Ecol. Model., 189, 25-48, 2005.

Thornton, P. E., Law, B. E., Gholz, H. L., Clark, K. L., Falge, E., Ellsworth, D. S., Goldstein, A. H., Monson, R. K., Hollinger, D., Falk, M., Chen, J., and Sparks, J. P.: Modeling and measuring the effects of disturbance history and climate on carbon and water budgets in evergreen needleleaf forests, Agr. Forest Meteorol., 113, 185-222, 2002.

Thornton, P. E., Running, S. W., and Hunt, E. R.: Biome-BGC: Terrestrial Ecosystem Process Model, Version 4.2 Final Release, Numerical Terradynamic Simulation Group, School of Forestry, University of Montana, Missoula, USA, available at: http://www. ntsg.umt.edu/project/biome-bgc (last access: 7 May 2014), 2005.
Timar, L.: Rural Land Use and Land Tenure in New Zealand, Motu Working Paper 11-13, Motu Economic and Public Policy Research, Wellington, 2011.

Timar, L. and Kerr, S.: Land-use Intensity and Greenhouse Gas Emissions in the LURNZ Model, Motu Working Paper 14-03, Motu Economic and Public Policy Research, Wellington, 2014.

Wang, Q., Watanabe, M., and Ouyang, Z.: Simulation of water and carbon fluxes using Biome-BGC model over crops in China, Agr. Forest Meteorol., 131, 209-224, doi:10.1016/j.agrformet.2005.06.002, 2005.

Wang, W., Ichii, K., Hashimoto, H., Michaelis, A. R., Thornton, P. E., Law, B. E., and Nemani, R. R.: A hierarchical analysis of terrestrial ecosystem model Biome-BGC: Equilibrium analysis and model calibration, Ecol. Model., 220, 2009-2023, 2009.

Warrick, R. A., Kenny, G. J., and Harman, J. J. (Eds.): The Effects of Climate Change and Variation in New Zealand: An Assessment Using the CLIMPACTS System, International Global Change Institute, University of Waikato, Hamilton, New Zealand, available at: http://docs.niwa.co.nz/library/public/ 0473079887.pdf (last access: 7 May 2014), 2001.

White, M. A., Thornton, P. E., Running, S. W., and Nemani, R. R.: Parameterization and Sensitivity Analysis of the Biome-BGC Terrestrial Ecosystem Model: Net Primary Production Controls, Earth Interact., 4, 1-85, 2000. 